\title{
Ev Dekorasyonunda Kullanılan Renklerin Tüketicilerin Satın Alma Davranışına Etkisi (The Effect of Colors Used in Home Decoration on Purchasing Behavior of Consumer)
}

\section{Şaban ALTIN iD a Behiye ÇİÇEK (iD b}

a Yozgat Bozok Üniversitesi, Sosyal Bilimler Meslek Yüksekokulu, Yozgat, Türkiye. saban.altin@bozok.edu.tr

b Yozgat Bozok Üniversitesi, Sosyal Bilimler Meslek Yüksekokulu, Yozgat, Türkiye.behiye.çiçek@bozok.edu.tr,

\begin{tabular}{ll}
\hline MAKALE BILGISI & ÖZET \\
\hline Anahtar Kelimeler: & Amaç - Renk olgusu, kişilerin çevresi ile olan ilişkilerini, günlük stres ve moral durumunu, tüketim \\
Renk & ve üretim durumunu, etkinlik ve yaptırım gücünü, iş faaliyet durumunu etkilemektedir. Bu etki, \\
Renklerin Anlamları & tüketicilerin ev dekore ederken ve dekorasyon ürünlerini satın alırken de önemli bir yere sahiptir. Bu \\
Renklerle Pazarlama & nedenle araştırmanın amacı, tüketicilerin ev dekorasyon ürünlerini satın almalarında ürünlerin \\
Tüketici Davranışları & renkleri ile tüketicilerin satın alma kararları arasındaki ilişkileri ve etkileri incelemektir. Ayrıca \\
Satın Alma & demografik değişkenlere göre renk tercihlerinin ve satın alma kararlarının farklılık gösterip \\
& göstermediğinin ortaya konulması amaçlanmaktır.
\end{tabular}

Yöntem - Araştırmanın bu kısmında, yargısal örnekleme yöntemi ile belirlenmiş örneklem grubuna yüz yüze anket yöntemi uygulanmıştır. Elde edilen veriler, analize uygun hale getirildikten sonra, verilerin dağılımlarına ilişkin frekans tablolarına, ortalamadan sapmaların ölçülmesi için Anova ve ttestine, bağımlı ve bağımsız değişken arasındaki ilişkilerin ölçülmesi için korelasyon analizine,

Gönderilme Tarihi 28 Mayıs 2019

Revizyon Tarihi 6 Aralık 2019

Kabul Tarihi 26 Aralık 2019

Makale Kategorisi:

Araştırma Makalesi

\begin{tabular}{l}
\hline ARTICLE INFO \\
\hline Keywords: \\
Colors \\
Meaning of Colors \\
Marketing With Colors \\
Consumer Behavior \\
Purchasing
\end{tabular}

Received 28 May 2019

Revised 6 December 2019

Accepted 26 December 2019

Article Classification:

Research Article decoration products.

değişkenlerin etkilerinin ölçülmesi için regresyon analizine başvurulmuştur.

Bulgular - Verilerden elde edilen bulgulara göre, en çok tercih edilen rengin mavi olduğu, sevilmeyen renklerin ise turuncu e pembe olduğu göstermektedir. Memurların, ev dekorasyon ürünlerini satın alma konusunda işçilere, ev hanımlarına ve öğrencilere göre farklı görüşlere sahip olduğu görülmektedir. Tüketicilerin satın alma kararları ile dekorasyon ürünlerinin renkleri arasında pozitif yönlü ilişki ve etki olduğu görülmektedir.

Tartışma - Araştırmanın bulgularına göre, tüketicilerin renklere ilişkin değerlendirmelerine etki eden faktörlerin artırılması durumunda satın alma davranışlarının pozitif yönlü etkileneceği ve satın almaların artış göstereceği beklenmektedir. Bu sonuçlara göre dikkat edilmesi gereken unsur ev dekorasyonu tamamlayıcı parçalarının tercihinde söz konusu alışverişi yapan kişi eğer kadın ise odanın dizaynında kullanılan renklerin yoğunluğu sorularak ona göre tavsiyelerde bulunulabilir.

\footnotetext{
Discussion - According to the findings of the research, it is expected that the purchasing behaviors will be affected positively and the acquisitions will increase if the factors that affect the evaluations of the consumers are increased. According to these results, the element that should be considered is the choice of complementary pieces of home decoration, the person in question is the woman who makes the shopping in question and the intensity of the colors used in the design of the room can be asked.
}

ABSTRACT

Purpose - Color fact, their relations with the environment of people, everyday stress and moral status, consumption and production status, effectiveness and enforcement powers, the situation affects business operations. This effect has an important place in decorating consumers' home and buying decoration products. Therefore, the aim of the study is to examine the relationships between the colors of the products and the purchasing decisions of the consumers in the purchase of home decoration products by the consumers. In addition, it is aimed to determine whether color preferences and purchasing decisions differ according to demographic variables.

Design/methodology/approach - In this part of the study, face-to-face survey method was applied to the sample group determined by judicial sampling method. After the data obtained were adapted for analysis, frequency tables related to the distribution of the data, Anova and t-test for the measurement of deviations from the average, correlation analysis for measuring the relationships between the dependent and independent variables, regression analysis were used to measure the effects of the variables.

Findings - According to the findings obtained from the data, it is most preferred blue color, which indicated that while unpopular color orange to pink. It is seen that the officers have different opinions about buying home decoration products according to the workers, housewives and students. It is seen that there is a positive relationship between the purchasing decisions of consumers and the colors of decoration products. 


\section{Giriş}

Renkler, çok eski çağlardan beri simgesel iletişim aracı olmuştur. Kişinin zevkini, kendine olan güvenini ve kişinin ruh halini yansitan unsurlardan birisi renktir. Her rengin insan psikolojisi üzerindeki farklı etkisi vardır. Bu nedenle renklerin duygulara aracılık ettiği bilinmektedir. Dolayısıyla renkler için iyi ve kötü anlamların yüklenmesi doğru değildir. Aksine insanların duygularına tercüman olmaktadır. Bununla beraber renk kavramı, insan yaşamının her alanında onları etkilemede, estetik ve rahatlık görüntüsü sağlamada denge unsuru olarak kullanılmaktadır. Yine renk unsuru, ev dekore dekorasyonunda önemli ögelerden biri olmuştur. Bir tasarımcl, iç mekâna hislerini katarken renk faktörünün, ürünleri fiziksel ve niteliksel olarak etkilediğini unutmamall, içerisinde yer alan tüm biçimler ve yüzeylerinde yine renk farklılıkları sayesinde daha iyi algılandığı bilmek durumundadır. Spence (2015) renkler üzerine yaptığ1 araştırmasında, renklerin insanlar üzerinde psikolojik olarak bir beklenti oluşturduğunu ve her zaman beklentiler dahilinde olamayabileceğini belirtmektedir. Bu durumun aslında doğuştan kazanılmış bir bilgi olmasa da yaşanarak öğrenilen bir bilgi olduğu belirtilmektedir (Yılmaz ve Erden, 2017: 266).

Modern pazarlama anlayışında, tüketicinin satın alma davranışını etkileyen pek çok faktörler bulunmakla beraber bu faktörlerden birisi de renk olmuştur. İnsanların mekânlarını ve eşyalarını her an değiştirme şansının olamayacağı gerçeği, renk seçiminin önemini ortaya çıkarmaktadır. Literatürde renklerin tüketici davranışlarına etkilerini ölçen çalışmalara yer verilmiştir. Akbaş (2006) tarafından yapılan çalışmada; ekonomik, stratejik, politik, Sosyo-kültürel ve psikolojik etkenlerden yer yer uzaklaşarak estetik ve fonksiyonel kaygıların otomobil iç mekânlarına yansıtılması ve ortaya çıkan ürünle kullanıcının beğenisine sunulma sürecinin tasarımcı ve pazarlama yönüne değinilmiştir. Çalışma sonucunda, otomobillerin kullanıııların isteklerine ve yaşam tarzlarına göre tasarlanması anlatılmıştır. Ustaoğlu (2007) tarafından İstanbul ilinde yapılan çalışmada; renkler, nasıl oluştukları ve kıyafetlerdeki renklerden odalardaki renklere kadar bütün renk kullanımlarının insanları nasıl etkilediğini ve onların bakış açılarını anlamaya yönelik çalışma yapılmıştır. Yapılan çalışma sonucunda, cinsiyetler arasında renk tercihi ve renk kullanımı arasında anlamlı bir ilişki olduğu saptanmıştır. Memiş (2007) tarafından İstanbul ilinde yapılan çalışmada renk görme modellerinden bazıları makul doygunlukta ve eşit parlaklıkta katılımcılara sunulmuştur. Yapılan çalışma sonucunda, kadın ve erkekler arasında renk algısının farklı olmadığı sonucuna ulaşılmıştır. Çitoğlu (2008) tarafından Polonya, Japonya, Almanya, Rusya, Amerika ve Türkiye'deki temsili afiş tasarımı çalışmanın örneklemi olmuştur. Yapılan çalışmada, afiş tasarımlarının özelliklerini belirlemek amaçlanmıştır. Çalışma sonucunda, bazı ülkeler belli renkleri oldukça fazla kullanırken diğer bir ülke bu renkleri kullanmamıştır. Ülkelerin renk kullanımında bazı renkleri çok fazla kullanması o renge yüklediği anlamdan kaynaklı olabileceği sonucuna ulaşılmıştır.

Literatürden elde edilen bilgilere göre bu araştırmanın, tüketicilerin ev dekorasyon ürünlerini satın almalarında ürünlerin renkleri ile tüketicilerin satın alma kararları arasındaki ilişkiler ve renklerin satın alma kararlarına etkileri incelemek amaçlanmaktadır. Araştırma, ayrıca demografik değişkenlere göre renk tercihlerinin ve satın alma kararlarının farklılık gösterip göstermediğinin ortaya konulması ve tüketicilerin ev dekorasyonunda renklere verdikleri önemi ve satın alma kararlarına etkisini belirlemeye yardımcı olacaktır. Araştırmanın tüketici davranışları araştırmalarına önemli katkılar sağlayacağı, gerek sektör temsilcilerine, gerekse bu alanda akademik çalışmalar yapmayı hedefleyen araştırmacılara katkıda bulunacağı düşünülmektedir.

\section{Renkler, Özellikleri ve Taşıdıkları Anlamlar}

En temel anlamıyla renk, nesnelerden yansıyarak gelen ışınların (1şık) görsel algıda oluşturduğu duygudur (İpek, 2014: 11). Diğer bir deyişle renk, ışı̆̆ın kendi öz yapısına veya cisimler tarafından yayılma şekline bağlı olarak göz üzerinde yaptığı etkidir (Çitoğlu, 2008: 23).

Her rengin taşıdığı anlamlar ve özellikler farklılık göstermektedir. Bazı renkler huzur, sıcaklık, hafiflik, dinginlik, sevinç verirken bazısı da korku, soğukluk, pasiflik ve üzüntü verebilmektedir. Renk olgusunun, psikolojik faktörlerden algılama ile ilgili olduğu belirtilmektedir. Tüketicilerin ürün ve hizmetleri tüketimi ile ilgili seçimlerini yaparken renklerle yüz yüze geldiği ve algılama sürecinde bu uyarıcılardan etkilendiği bilinmektedir. Renk olgusu tüketicilerin algılamalarında önemli bir yere sahip olduğu bilinmektedir (Engel vd.,1995). Bu durumda renkleri tek tek incelemek daha doğru olacaktır. 
Beyaz, bütün renkleri içinde barındırır. Batı kültüründe saflık ve yalınlığı temsil etmekle birlikte bazı toplumlarda matem rengi olarak kabul edilmektedir. Renklere yüklenen anlamlar kültürlere göre farklılık gösterebilmektedir (Ahbap, 2014: 44).

Siyah, beyazın zıttı olan siyah, iyi-kötü, gündüz-gece, yaşam-ölüm gibi var olan doğal ikilemlerin 'diğer' rengidir. Bu renk, pişmanlığı, suçluluğu sembolize edebileceği gibi, derinliği, sessizliği ve sonsuzluğu simgeler (Özdemir, 2005: 393). Ayrıca siyah renk, prestij, soğuk, gizem, hırs ile ilişkilendirilmektedir. Otorite ve gücün rengi olarak bilinmektedir (Elliot ve Maier, 2007)

Kırmızı, sıcak, canlandırıcı bir renktir ve insanlara enerji verir. Uzun süre seyredildiğinde gerginlik oluşturabilmektedir. Kırmızının aşıladığı en önemli duygu sıcaklık, heyecan ve bir an önce harekete geçme istemidir. Motivasyonu, teşviki, aktiviteyi ve ihtirası sembolize eder (Mehmeti, 2003: 125).

Sarı, en parlak renktir. İlkel toplumlarda, sonsuza dek yaşamla özdeşleştirilmiştir. Bolluk, kutsallık, güneş ve zenginlik simgesidir. Karanlığın içinden çıkan ışık anlamında, aydınlığın simgesi olarak kabul edilmiş ve bu anlamıyla bilgiyi temsil etmektedir (Şen, 2007: 12).

Mavi, otoriteyi, ağırbaşlılı̆̆ı, bağlılı̆̆ı, gerçeği ve bilgeliği simgelese de aynı zamanda depresyon, keder ve yalnızlığı da çağrıştırmaktadır. Mavi; güven, güç, tutuculuk, inanç, istikrar ve güvenlik gibi kavramları akla getirmektedir (Durmaz, 2009: 77). Madlen ve arkadaşlarının (2000) mavi rengi, sağlık, dürüstlük ve güvenle ilişkilendirmiş ve bankaların logolarında ve levhalarında mavi rengi kullanmalarının da güven ve güç ilişkili olduğunu, aynı zamanda hastalar üzerinde de mavi rengin korkuları azaltıcı ve sakinleştirici özelliği olduğu belirtilmektedir (Grossman ve Wisenblit, 1999; Madlen vd 2000; Hopia vd., 2015: 79; Akgül ve Güneş, 2016: 4; yılmaz ve erden, 2017: 268). Diş doktorlarının muayenehanelerinin duvarlarını maviye boyayarak hastalarının korkularını azaltmaya ve onları sakinleştirmeye çalışırlar

Yeşil, denge, uyum ve koruma özelliklerini barındırmaktadır. Eşitliği, gençliği, kıskançlığı ve geçiciliği simgelemektedir. Renklerin en sakinidir, ne sevinci ne üzüntüyü ifade eder. Güvenliği ve özgürlüğü sembolize etmektedir (Yazıc1, 2009: 51).

Turuncu, neşe, canlılık, dışa dönüşlük, hareketlilik, coşku, dost edinme isteği ve sosyalleşme göstergesidir. Muhakeme yapma yeteneğini güçlendirdiği söylenebilir. Mantıksal gücü artırmaktadır (İpek, 2014: 75).

Mor, gururun, ihtişamın, asaletin rengi olarak tanımlanabilmektedir. Renklerin anlamları farklı kültürlere göre değişebilmektedir. Mor renk, pazarlama iletişiminde en genel alg1 olarak asalet ve imparatorluk rengi olarak bilinmektedir (Yllmaz ve Erden, 2017: 267).

Kahverengi, hüzünlü ve düşüncelere sürükleyicidir. Dindarlığı temsil etmektedir. Kahverengi, toplumsal düzene ve aileye duyulan ihtiyacı vurgulamaktadır. Genellikle insanların sosyal yönüne bir denge getirir. Başka bir deyişle, kişinin ayaklarının yere basmasını sağlamaktadır (Sarıkaya ve Sütütemiz, 2004: 224).

\section{Renklerin Tüketici Davranışlarına Etkisi}

Soyut kavramları ve düşünceleri sembolleştiren, bireyin hayal dünyasını, istek ve arzularını açığa çıkaran; zaman ve mekanı hatırlatan; duygusal ve görsel cevaplar üreten renk; aynı zamanda, kurumsal kimliklerin ve markaların ana öğesi olarak faaliyet gösterir; ikna etmede, iletişim kurmada ve bir ürüne insanların ilgisini çekmede önemli bir rol oynamaktadır (Öztuna, 2007: 91). Renkler; insanların duygusal, zihinsel ve fiziksel yapılarını etkilemekte yani insan psikolojisi üzerinde etkili olmaktadır (İçli ve Çopur, 2008: 25). Renkler, alışveriş psikolojisini ya da tüketici psikolojisini destekler. Renk seçiminin diğer ucunda, tanımlanmış bir insan psikolojisi bulunmaktadır. Bu durumda, insan psikolojisini oluşturan kişilik özellikleri, renk kararlarını belirleyen değişkenlerden biri olmaktadır (Durmaz, 2009: 98). Tüketiciler hayatları boyunca pek çok kez ürünler, ambalajları, mağaza Ürün dizaynı, reklamlar ve buralarda kullanılan renklerle karşı karşıya gelmekte ve algılama sürecinde bu uyaranlardan etkilenmektedir (Bahattin, 2013: 67). Renklerin insanlar üzerindeki bu psikolojik etkileri nedeniyle işletmeler pazarlama çabaları içerisinde ürün ambalajından başlayıp, reklama, mağaza atmosferine kadar pek çok konuda renk ve kullanımına dikkat etmek durumundadır (Ceylan ve Eliri, 2014: 413). Yine ambalajın rengi, bir ürünü diğerlerinden ayırır, tanımayı kolaylaştırdığı belirtilmektedir (Gönen ve Özmete, 2007: 54). Örneğin, Kodak sarısı, Fuji yeşili, Coca Cola'nın kırmızısı, Bayer aspirinin yeşili bütün dünyada ürünü, ambalajını ve markasını renklerle güçlendirmenin önemli örneklerindendir (Meyers ve Lubliner, 2003; Bahattin, 2013: 67). Tüketicilerin satın 
alma karar süreci tatmin edilmemiş bir ihtiyacın ortaya çıkmasıyla başlar. Ortaya çıan bu ihtiyaç tüketicide bir gerginlik meydana getirir ve tüketiciyi bu gerilimi ortadan kaldırmaya teşvik eder. Tüketici bu gerilimi ortadan kaldırmanın yolunu aramaya çalışır (Ahbap, 2014: 31). Problem çözme işlemi olarak da tanımlanan ilk süreç, ihtiyacın hissedilmesiyle başlar. İkinci aşamada, bu ihtiyacı karşılayacak ürünler belirlenir. Üçüncü aşamada, belirlenen ürünler arasından kişinin ihtiyacını en yüksek düzeyde tatmin edecek ürünlerin özelliklerine ilişkin değerlendirilmeler yapılır. Tüketiciler alternatifleri değerlendirirken ürünün fiyatı, markası, ambalajı, kalitesi gibi konuları göz önünde tuttuğu için, ambalaj tüketicilerin bu alternatifleri değerlendirmesinde önemli bir rol oynamaktadır. Ambalajların dikkat çekici ve hedef kitlenin ilgisine ve ihtiyacına yönelik ustaca seçilmiş renklerle hazırlanmış olması satın alma kararını olumlu yönde etkilemektedir. Dördüncü aşamada, yapılan değerlendirmeler sonucunda satın alma kararı verilir ve birey malın cinsine, markasına, fiyatına, rengine, miktarına, ambalajına bakarak satın alma işlemini gerçekleştirir. Son aşamada ise satın alma sonrası değerlendirme, tatmin ya da tatminsizlik olarak yapılmaktadır (Odabaşı ve Barış, 2013: 333).

Renklerin bilinçli kullanımı, satışta önemli bir etkendir. Ürünlerin renkli sunuşları siyah beyaz sunuma kıyasla tüketicinin ilgisini daha fazla üzerine çeker. Renk, görsel bir izlenimi tüketicinin hafızasına yerleştirir ve ürüne prestij kazandırır. Rengin sahip olduğu "dikkat çekme, ilgiyi arttırma ve prestij kazandırma" gibi üç önemli niteliği, önemli bir satış arttırıcı faktör olarak kendini göstermektedir (Mehmeti, 2003: 120).

İnsan hayatında her şeyin içinde var olan, düşünce ve duyguları uyandıran, motivasyonu arttıran satın alma alışkanlıkları üzerinde renklerin önemli etkileri bulunmaktadır. (Özcan, 2018: 86). İşletmelerin pazarlama çabalarına ilişkin yaptıkları araştırmalarda; nesnelerin \%3'ü dokunarak, \%3'ü koklayarak, \%3'ü tadarak, \%13'ü işiterek, \%78'i görerek algılandığı sonucuna ulaşılmış ve ilk 9 saniye içinde seçimi etkileyen en önemli unsurun renk olduğunu ortaya konularak tüketici davranışları açısından görsel iletişimin önemli olduğu vurgulanmıştır (İçli ve Çopur, 2008: 25).

Ürünün yapısına uygun seçilen renklerle, uyumlu yazı ve biçimlerle tasarlanmış, çekici, güzel görünümlü bir ambalaj, tüketiciyi olumlu yönden etkiler (Bahattin, 2013: 67). Ürün ambalajının rengi değiştirildiğinde tüketici satın alma eğilimi gösterebileceği gibi önceden satın aldığı bir ürünü almama eğilimi de gösterebilmektedir (Yazıc1, 2009: 61).

\section{4. İlgili Literatür}

Renklerin insan davranışlarına etkileri ile ilgili literatürde farklı alanlarda yapılmış araştırmalara rastlanmaktadır. Örneğin, Akbaş (2006) tarafından yapılan çalışmada; ekonomik, stratejik, politik, Sosyokültürel ve psikolojik etkenlerden yer yer uzaklaşarak estetik ve fonksiyonel kaygıların otomobil iç mekânlarına yansıtılması ve ortaya çıkan ürünle kullanıcının beğenisine sunulma sürecinin tasarımcı ve pazarlama yönüne değinilmiştir. Çalışma sonucunda, otomobillerin kullanıcıların isteklerine ve yaşam tarzlarına göre tasarlanması anlatılmıştır. Ustaoğlu (2007) tarafından İstanbul ilinde yapılan çalışmada; renkler, nasıl oluştukları ve kıyafetlerdeki renklerden odalardaki renklere kadar bütün renk kullanımlarının insanları nasıl etkilediğini ve onların bakış açılarını anlamaya yönelik çalışma yapılmıştır. Yapılan çalışma sonucunda, cinsiyetler arasında renk tercihi ve renk kullanımı arasında anlamlı bir ilişki olduğu saptanmıştır. Bunun yanı sıra farklı yaşlarda hemcinslerin renk tercihleri arasında anlamlı bir ilişki bulunamamıştır. Memiş (2007) tarafından İstanbul ilinde yapılan çalışmada renk görme modellerinden bazıları makul doygunlukta ve eşit parlaklıkta katılımcılara sunulmuştur. Yapılan çalışma sonucunda, kadın ve erkekler arasında renk algısının farklı olmadığı sonucuna ulaşılmıştır. Çitoğlu (2008) tarafından Polonya, Japonya, Almanya, Rusya, Amerika ve Türkiye'deki temsili afiş tasarımı çalışmanın örneklemi olmuştur. Yapılan çalışmada, afiş tasarımlarının özelliklerini belirlemek amaçlanmıştır. Çalışma sonucunda, bazı ülkeler belli renkleri oldukça fazla kullanırken diğer bir ülke bu renkleri kullanmamıştır. Ülkelerin renk kullanımında bazı renkleri çok fazla kullanması o renge yüklediği anlamdan kaynaklı olabileceği sonucuna ulaşılmıştır. Koca ve Koç (2008) tarafından Ankara ilinde yapılan çalışmada, çalışan kadınların giysi seçimlerini ve giysilerindeki renk tercihlerini belirlemek amaçlanmıştır. Çalışma sonucunda, çalışan kadınların büyük bir çoğunluğunun klasik ve spor giyimi tercih ettikleri, klasik giyim tarzını genellikle işçi ve memurların, spor giyim tarzını ise öğrenci ve serbest meslek sahiplerinin tercih ettiği tespit edilmiştir. Bu tercihlerde çalışma koşullarının ve sektör tipinin giyim tercihlerini etkilediği, resmi ortamlarda daha ciddi ve resmi görüntü veren giysiler tercih edildiği sonucuna ulaşılmıştır. Eti İçli ve Çopur (2008) tarafından yapılan 
çalışmada, pazarlama iletişiminde görsel unsurlardan özellikle rengin etkisinin olduğu düşülmüştür. Çalışma sonucunda, renklerin öncelikle görsel olarak dikkat çekiciliği sağlayarak tüketicinin ürüne yönelmesini sağlarken, alışveriş yapılan ortamların renkleri de tüketici davranışlarına yansıttığını, özellikle kurum kimliği, mağaza dekorasyonu ve ürün ambalajlarında bu yansıma daha net bir biçimde görüldüğü sonucuna ulaşılmıştır. Durmaz (2009) tarafından yapılan çalışmada, hızlı tüketim ürünü ambalajlarında rengin etkisini analiz etmeyi ve renk üzerinden tüketici ile kurulan iletişim yapılarını belirleyen tasarım kararlarının incelenmesi amaçlanmıştır. Yapılan çalışma sonucunda, ambalaj tasarımları için alınacak kararlarda, pazarlama uzmanlarının strateji geliştirmekte kullandıkları temel prensiplerin tasarımcı tarafından da bilinmesi ve tasarım ile ilişkilendirmesi uzmanlık alanı için gerekli olduğu sonucuna ulaşılmıştır. Yazıcı (2009) tarafından İstanbul ilinde yapılan çalışmada, tüketicilerin yaşam tarzına bağlı olarak, gıda ürünleri ambalajlarında renk tercihlerini ortaya çıkarmak amaçlanmıştır. Yapılan çalışma sonucunda, tüketicilerin yaşam tarzları, ambalajın özellikleri ve ambalaj renk tercihlerini etkilediği sonucuna ulaşılmıştır. Akkuş Karkın (2009) tarafından yapılan çalışmada; otel işletmelerindeki müşteri memnuniyeti üzerinde önemli bir etkisi olduğu düşünülen hizmet atmosferi üzerinde durulmuş ve müşterilerin oteli değerlendirmede yararlanacakları atmosferik ipuçları fiziksel ve sosyal çevre unsurları ele alınmış olup bu bağlamda, aydınlatma, renk, müzik, koku, gürültü gibi unsurlar fiziksel çevre unsuru olarak değerlendirilirken ortamda bulunan diğer müşteriler ve çalışanlar ise sosyal çevre unsuru olarak değerlendirilmiştir. Çalışma sonucunda, hizmete özgü farklılıkların ve bunların pazarlama üzerindeki etkisinin farkında olan ve tüketicilerin işletmeleriyle ilgili algılamalarını etkileyerek, memnuniyet düzeylerini yükseltmek isteyen hizmet işletmelerinin söz konusu bahsi geçen hizmet atmosferini ön planda tutmaları gerektiği sonucuna ulaşılmıştır. Ellialtı (2009) tarafından İstanbul ilinde yapılan çalışmada, ürün özelliklerinin, görece ürün kalitesinin ve tüketici etnosentrizminin kozmetik sektöründe yerli ürün satın alma eğilimine etkisi incelenmiştir. Yapılan çalışma sonucunda, görece ürün kalitesi ve tüketici etnosentrizmi değişkenlerinin yerli ürün satın alma eğilimi üzerinde etkili olduğu ortaya çıkmıştır. Yani tüketicinin etnosentrizim düzeyi ve görece ürün kalite algısı düzeyi pozitif yönde arttıkça yerli ürün satın alma eğilimi de artmaktadır. Özer (2012) tarafından yapılan çalışmada, toplumları düzenleyen bir unsur olarak rengin insan yaşamındaki yaygın kullanımının ve kişilerarası iletişimde taşıdığı rolün önemine değinmektedir. Bu kapsamda, renklerin iletişim ile ilişkisi açıklanarak oluşturduğu toplumsal anlam birliği literatür bilgisiyle yorumlanması amaçlanmıştır. Çalışma sonucunda, toplumsal ve kişilerarası ilişkiler bağlamında rengin doğasında bilgi aktarma ve iletişim salama görevi bulunduğu görülmektedir. Dolayısıyla renk ve iletişim arasındaki ilişki toplumlar ve insanlar arasında bir etkileşim oluşturduğu sonucuna ulaşılmıştır. Bahattin (2013) tarafından Ankara ilinde yapılan çalışmada, ambalaj tasarımda kullanılan renklerin tüketici üzerindeki etkileri ve grafik öğrencilerinin konu üzerindeki farkındalığının belirlenmesi amaçlanmıştır. Yapılan çalışma sonucunda, öğrencilerin aldıkları renk bilgisinin ambalaj tasarımı uygulaması için yetersiz olduğu görülmüş bunun sonucunda katılımcıların mezun olduktan sonra kendilerini sektörde geliştirdikleri sonucuna ulaşılmıştır. Öztürk Ahbap (2014) tarafından İstanbul ilinde yapılan çalışmada, renklerin pazarlama süreci ve satın alma davranışı üzerindeki etkileri ile renklerin ev mobilyası sektöründe tüketici tercihlerinin nasıl etkilediği öğrenmek amaçlanmıştır. Yapılan çalışma sonucunda, renklerin tüketici karar verme sürecinde tercihlerini yaparken son derece etkili olduğu sonucuna ulaşılmıştır. İpek (2014) tarafından Ankara ilinde yapılan çalışmada; yalnızlık duygusu ve bu duygunun yarattığ1 psikolojik durumların resim yaptırma yoluyla fark edilmesi ve tedavi süreci için gerekli yönlendirmelere katkıda bulunmak amaçlanmıştır. Çalışma sonucunda, yalnız çocukların belirlenmesinde ve bu çocukların gerekli yerlere yönlendirilmesinde resmin önemli bir rolü olduğu ortaya çıkmıştır. Çocuğun resimle anlatımının sözel ifadeden daha kolay ve derinlemesine bir anlatım yöntemi olduğu görülmüştür. Baykaldı (2015) tarafından İstanbul ilinde yapılan çalışmada; tüketicilerin mağaza atmosferi faktörlerinden renk, koku, çekicilik ve müziğin tüketici tutumuna etkisi ve tutumu oluşturan temel öğeler ile tüketicilerin demografik özellikler arasındaki ilişkinin ortaya konulması amaçlanmıştır. Çalışma sonucunda, mağaza atmosferini oluşturan faktörlerden renk, müzik ve koku faktörlerinin tüketici tutumuna etkisi incelendiğinde müzik faktörünün ön plana çıtığı, tüketici tutumu üzerinde kuvvetli bir etkisinin olduğu görülmüştür. Çeken ve Yıldız (2015) tarafından yapılan çalışmada, seçilen basılı reklamlar renk boyutunda incelenerek, algılama açısından farklı renklerin farklı karakterlere sahip olduğu söylemi ortaya konulmak istenmiştir. Çalışma sonucunda, çevredeki nesnelerin algılanmasında renklerin rolünün büyük olduğu sonucuna ulaşılmıştır. Şen (2015) tarafından Bursa ilinde yapılan çalışmada; bir iletişim aracı olan renklerin 
her birinin farklı anlamlar ifade ettiği, bir algı ve duygu yarattığı gerçeği düşünülerek, pazarlama uygulamalarının her alanında bu unsurun üstlendiği rolün yorumlanması amaçlanmıştır. Çalışma sonucunda, bir simgesel iletişim aracı olan renk, pazarlama iletişimindeki uygulamalarında, güçlü anlamları ve ifade ettikleri ile tüketicilerin algısında ve satın alma davranışlarında direkt etkili bir konumda olduğu bilgisi ortaya çıkmıştır. Akgül ve Güneş (2015) tarafından yapılan çalışmada; üniversitede okuyan 18-24 yaş aralığındaki gençlerin marka farkındalığı üzerinde renklerin ne derece etkili olduğunu tespit etmek ve renklerin anlamlarının doğru algılanıp algılanmadığını ve renklere göre en bilinen markaları belirleme amaçlanmıştır. Çalışma sonucunda, renklerin literatürdeki anlamları incelenmiş olup bu incelemeye göre renklerin içerdikleri anlamlarına göre sıfatlar ve renkler eşleştirilmiştir. Bazı renklerin literatürdeki anlamlarıyla eşleşmediği görülmüştür. Bu eşleşmemenin nedeni ise kültürler arasında farklı anlamları olduğundan kaynaklı olduğu düşünüldüğü sonucuna ulaşılmıştır. Yılmaz ve Erden (2017) tarafından Manisa ili Salihli ilçesinde yapılan çalışmada; renklerin çorbaların tat algısı üzerindeki etkilerinin belirlemesi amaçlanmıştır. Çalışma sonucunda, sıcak renklerin literatür ile aynı doğrultuda olarak iştah açan renkler olduğu görülürken, soğuk renklerden yeşil, katılımcılar tarafından iştah açan renkler arasında seçilmiştir. Yine sağlık ile ilişkilendirilen renklerin iştah üzerinde olumlu etkiler bıraktığı sonucuna ulaşılmıştır. Özcan (2018) tarafından yapılan çalışmada, renklerin tüketimde ve sağlıkta önemi üzerinde durulmuştur. Yapılan çalışma sonucunda, insanların sağlıklı beslenmesinde öncelikle kaliteli ürünlerin tüketiciye sunulması gerektiği sonucuna ulaşılmıştır. Bunun için de kaliteli yetiştiricilik yapılması, uygun ambalajlama, uygun taşıma, uygun muhafaza ve uygun pazarlama yapılarak kalitenin en az kayıpla tüketiciye ulaştırılması gerektiği sonucunu ulaşılmıştır. Ayrıca tüketiciye kaliteli ürün sunma yanında sağlıklı yaşam için tüketimdeki çeşitliliğin önemininde anlatılmasının gerekli olduğunu belirtmiştir.

\section{Araştırmanın Yöntemi}

\subsection{Araştırmanın Amacı ve Yöntemi}

Yapılan bu araştırmanın amacı, tüketicilerin ev dekorasyon ürünlerini satın almalarında ürünlerin renkleri ile satın alma kararları arasındaki ilişkileri ve renklerin satın alma kararlarına etkilerini ölçmektir. Araştırmadan elde edilen verilerin analiz yönteminde ise, tanımlayıcı istatistik yöntemlerinden ve tahminleyici istatistik yöntemlerinden yararlanılmaktadır. Değişkenler arasındaki ilişkilerin ölçümünde korelasyon analizlerinden, bağımsız değişkenlerin bağımlı değişkenlere etkilerini ölçmek için de doğrusal regresyon analizinden yararlanılmaktadır. Ayrıca tüketicilerin cinsiyetleri, yaş dağılımları, gelir düzeyleri ve eğitim seviyelerine göre renklere ilişkin görüşlerinin farklılık gösterip göstermediğinin ölçmek için, Bağımsız t-testi ve tek yönlü anova analizlerinden yararlanılmaktadır. Örneklem grubunun demografik değişkenleri ile en çok tercih edilen renklere ilişkin değerlendirmelerine ait dağılımların ölçümünde çapraz tablolara yer verilmektedir. Araştırmada nicel araştırma yöntemi seçilmiş ve örneklem grubuna uygulanmak üzere anket form hazırlanmıştır. Anket formunda "Satın Alma Davranışı Ölçeği ve renklere ilişkin değerlendirmeler ölçeği" olmak üzere iki ayrı ölçekten yararlanılmaktadır. Araştırmada kullanılan tüm ölçeklerin geçerliliği ve güvenirlilik çalışması yapılmıştır.

\subsection{Araştırmanın Ana Kütlesi, Örneklemi ve Kısıtları}

Araştırmadaki veriler yüz yüze anket yöntemi ile toplanmış olup araştırmanın örneklemi, Yozgat ilinde yaşayan tüketiciler arasından yargısal örnekleme yöntemi ile seçilmiş 218 kişiden oluşmaktadır. Araştırmanın en önemli kısıtı sonuçların Yozgat İli ile sınırlı olmasıdır. Ayrıca sonuçlar tüketicilerin tüketim alışkanlıklarına göre farklılık gösterebilmektedir. Araştırmada tüketicilerin sorulara içtenlikle cevap verdiği varsayılmaktadır. Bu nedenle araştırmada yer alan diğer bir kısıtta, değişkenlerin, soyut ve öznel ifadeler içermesinden dolayı nesnel değerlendirilmesinde sorunlar yaşanabilmesidir. Araştırma tek bir ilde yapıldığı için genellebilirliği mümkün görünmemekle beraber; araştırmanın farklı bölgelerde ve farklı illerde yapılarak genellebilirliğinin arttırılması gerekmektedir.

\subsection{Verilerin Yeniden Düzenlemesi ve Analizi}

Örneklemden elde edilen veriler, analiz edilmeden önce "Missing Value (Kayıp Değer)",ve “Outlier (Uç Değer)" analizleri yapılarak 30 adet veri araştırmaya dahil edilmemiştir. 188 veri yeniden düzenlenmiştir. Ayrıca araştırmada kullanılan ölçeklerin geçerlilik ve güvenilirlik analizlerinde her bir ölçeğin Cronbach Alfa değerlerine bakılmıştır. 


\subsection{Araştırmada Kullanılan Ölçekler}

Birinci bölümde katılımcıların ev dekore ederken renklere verilen önemin belirlenmesi amacıyla, toplam 11 maddeyi kapsayan bir ölçek oluşturulmuştur. Renklere ilişkin değerlendirmeler ölçeği: Dekorasyon ürünlerinde renklere verilen önemi ölçmek için Koca ve Koç (2008), Ahbap (2014) ve Bahattin (2013) çalışmalarındaki ölçek maddelerinden yaralanarak 6 madde kullanılmıştır. Satın Alma Davranışı Ölçeğinde ise Timm (2002), Tomer (2003), Raykov ve Marcoulides (2006), Jaffe (1994), Worth, Smith ve Mackie (1992) tarafından geliştirilen ve Yılmaz vd.(2009) ile Yağcı, İlarslan (2010)tarafından Türkçe 'ye uyarlanan 5 madde kullanılmıştır. İkinci bölümde demografik bilgilere (cinsiyet, medeni durum, yaş, öğrenim düzeyi, gelir) yer verilmiştir. Anket formunun üçüncü bölümünde ise katılımcıların ev dekorasyon ürünleri ve renkler ile ilgili görüşlerine yer verilmiştir.

\subsection{Araştırmanın Modeli ve Hipotezlerin Oluşturulması}

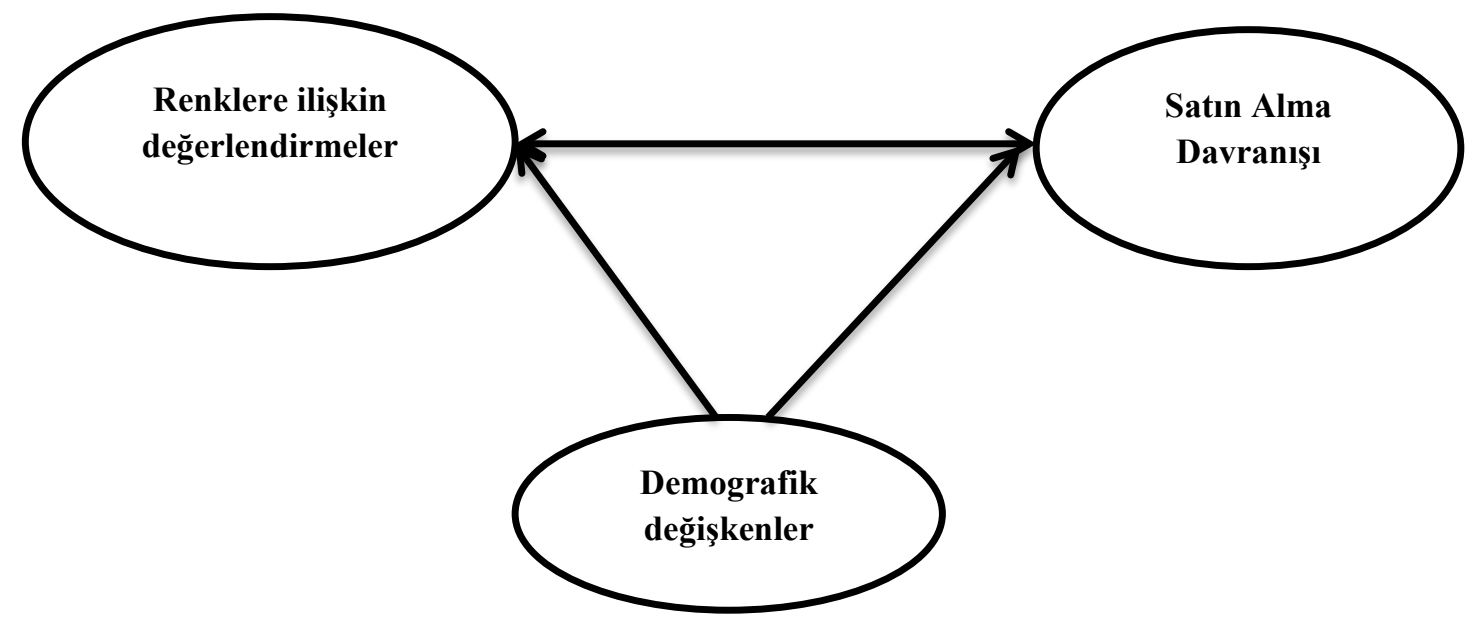

\section{Şekil 1: Araştırmanın Teorik Modeli}

Şekil 1'deki araştırma modeline göre tüketicilerin demografik değişkenlerinin (gelir, yaş, cinsiyet v.b.) satın alma davranışlarını ve renklere ilişkin değerlendirmelerini etkilediği düşünülmektedir. Ayrıca tüketicilerin renklere ilişkin değerlendirmeleri ile satın alma davranışları arasında pozitif veya negatif ilişkilerin olduğu düşünülmektedir. Bu doğrultuda, teorik modelde yer alan değişkenler arası etkiler ve literatürde yer alan bilgilere göre, araştırmanın hipotezleri aşağıda yer alan başlıklar altında geliştirilmiştir.

\section{Araştırmanın Hipotezleri:}

H1: Tüketicilerin satın alma kararları cinsiyetlerine göre farklılık gösterir

H2: Tüketicilerin satın alma kararları gelir düzeylerine göre farklılık gösterir.

H3: Tüketicilerin satın alma kararları eğitim düzeylerine göre farklılık gösterir

H4: Tüketicilerin satın alma kararları meslek gruplarına göre farklılık gösterir

H5: Tüketicilerin renklere ilişkin değerlendirmeleri cinsiyetlerine göre farklılık gösterir

H6: Tüketicilerin renklere ilişkin değerlendirmeleri gelir düzeylerine göre farklılık gösterir.

H7: Tüketicilerin renklere ilişkin değerlendirmeleri eğitim düzeylerine göre farklılık gösterir

H8: Tüketicilerin renklere ilişkin değerlendirmeleri meslek gruplarına göre farklılık gösterir

H9: Tüketicilerin renklere ilişkin değerlendirmeleri ile satın alma kararları arasında ilişki vardır.

H10: Tüketicilerin renklere ilişkin değerlendirmeleri, satın alma kararlarını etkiler.

\section{Bulgular}

\subsection{Tüketicilerin Demografik Özellikleri}


Ş. Altın - B. Çiçek 11/4 (2019) 3430-3447

Araştırmaya katılan 188 kişilik örneklem grubunun demografik özelliklerine ait bulgular Tablo 2'de yer almaktadır.

Tablo 1. Demografik Özelliklere İlişkin Bulgular

\begin{tabular}{|c|c|c|c|}
\hline \multicolumn{2}{|l|}{ Tüketici özellikleri } & $\mathrm{n}$ & $\%$ \\
\hline \multirow{5}{*}{ Yaş } & $20-30$ yaş & 82 & 43,6 \\
\hline & $31-40$ yaş & 53 & 28,2 \\
\hline & 41-50 yaş & 32 & 17 \\
\hline & 51 ve Üzeri yaş & 21 & 11,2 \\
\hline & Toplam & 188 & 100 \\
\hline \multirow{6}{*}{ Gelir Aralığ } & 1000 ve altı & 29 & 15,6 \\
\hline & 1001-1500 & 22 & 11,7 \\
\hline & $1501-2000$ & 17 & 9 \\
\hline & 2001-2500 & 49 & 26,1 \\
\hline & 2501 ve üzeri & 71 & 37,8 \\
\hline & Toplam & 188 & 100 \\
\hline \multirow{3}{*}{ Medeni Durum } & Bekâr & 109 & 58 \\
\hline & Evli & 79 & 42 \\
\hline & Toplam & 188 & 100 \\
\hline \multirow{2}{*}{ Cinsiyet } & $\begin{array}{l}\text { Kadın } \\
\text { Erkek }\end{array}$ & $\begin{array}{l}111 \\
77\end{array}$ & $\begin{array}{l}59 \\
41\end{array}$ \\
\hline & Total & 188 & \begin{tabular}{|l|}
100 \\
\end{tabular} \\
\hline \multirow{8}{*}{ Meslek } & Memur & 65 & 34,6 \\
\hline & İşçi & 13 & 6,9 \\
\hline & Esnaf & 19 & 10,1 \\
\hline & Ev Hanımı & 36 & 19,1 \\
\hline & Emekli & 10 & 5,3 \\
\hline & Serbest Çalışan & 19 & 10,1 \\
\hline & Öğrenci & 26 & 13,8 \\
\hline & Toplam & 188 & 100 \\
\hline \multirow{3}{*}{ Öğrenim durumu } & $\begin{array}{l}\text { İlk öğretim } \\
\text { Orta öğretim }\end{array}$ & $\begin{array}{l}15 \\
53\end{array}$ & $\begin{array}{l}20,2 \\
28,2\end{array}$ \\
\hline & Üniversite & 120 & 63,8 \\
\hline & Toplam & 188 & 100 \\
\hline
\end{tabular}

Tablo 1'e bakıldığında ankete katılan ve Yozgat ilinde yaşayan katılımcıların, \%43,6'sı (82 kişi) 20-30 yaş aralığındadır. Katılımcıların \%37,8'i (71 kişi) 2501- ve üzeri gelire sahiptir. \%58'i (109 kişi) bekâr olup, \%59'u (111 kişi) kadındır. Katılımcıların mesleklerine bakıldığında \%34,6 s1 (65 kişi) memurdur. Öğrenim durumları değerlendirildiğine ise katılımcıların \%63,8 (120 kişi) üniversite mezunu olduğu sonucuna ulaşılmıştır.

\section{2. Ölçeklerin Normal Dağılımına, Geçerlilik ve Güvenilirlik Analizlerine İlişkin Sonuçlar}

Araştırma verilerinin analizleri sonucunda elde edilen verilere göre, basıklık ve çarpıklık değerlerinin -1.5 ile 1.5 aralığında olduğu görülmüştür. Bu değerler, verilerin normal dağılma sahip olduğunu göstermektedir. (Tabachnick ve Fidell, 2012: 79, Kalaycı, 2009: 6 ) Ayrıca araştırmada kullanılan ölçeklerin geçerlilik ve güvenilirlik analizlerinde her bir ölçeğin Cronbach Alfa değerlerine bakılmıştır. Ölçeklerimizin 0.857 ile oldukça yüksek güvenilirliğe sahip olduğu görülmüştür. 
Ş. Altın - B. Çiçek 11/4 (2019) 3430-3447

Tablo 2. Verilerin Dağılımı ve Güvenilirliğine İlişkin Bulgular

\begin{tabular}{|c|c|c|c|c|c|c|c|c|c|}
\hline \multirow[t]{2}{*}{ Ölçekler } & \multirow[t]{2}{*}{ İfadeler } & \multirow{2}{*}{$\begin{array}{l}\mathrm{N} \\
\text { Statistic }\end{array}$} & \multirow{2}{*}{$\begin{array}{l}\text { Ort. } \\
\text { Statistic }\end{array}$} & \multirow{2}{*}{$\begin{array}{l}\text { Std. } \\
\text { Sapma } \\
\text { Statistic }\end{array}$} & \multicolumn{2}{|c|}{ Çarpıklık } & \multicolumn{2}{|l|}{ Basıklık } & \multirow{2}{*}{$\begin{array}{l}\text { Cronbach } \\
\text { Alfa }\end{array}$} \\
\hline & & & & & Statistic & $\begin{array}{l}\text { Std. } \\
\text { Error }\end{array}$ & Statistic & $\begin{array}{l}\text { Std. } \\
\text { Error }\end{array}$ & \\
\hline \multirow{6}{*}{$\begin{array}{l}\text { Renklere ilişkin } \\
\text { değerlendirmeler } \\
\text { ölçeği }\end{array}$} & R1 & 188 & 4,12 & 1,058 & $-1,003$ & 177 &,- 048 & ,353 & \multirow{6}{*}{857} \\
\hline & $\mathrm{R} 4$ & 188 & 2,99 & 1,179 &,- 039 & 177 &,- 902 & ,353 & \\
\hline & R6 & 188 & 4,32 & 830 & $-1,337$ & 177 & 2,068 & ,353 & \\
\hline & R8 & 188 & 3,32 & 1,177 &,- 377 & 177 &,- 782 & ,353 & \\
\hline & R10 & 188 & 3,99 & 1,193 & $-1,069$ & , 177 & ,160 & ,353 & \\
\hline & R11 & 188 & 3,90 & 1,025 &,- 771 & 177 & -,119 & ,353 & \\
\hline \multirow{5}{*}{$\begin{array}{l}\text { Satın Alma } \\
\text { Davranışı Ölçeği }\end{array}$} & $\mathrm{R} 2$ & 188 & 4,13 & 1,028 & $-1,195$ & 177 & ,904 & 353 & \multirow{5}{*}{843} \\
\hline & R3 & 188 & 3,65 & 1,203 &,- 592 & 177 & -609 & ,353 & \\
\hline & R5 & 188 & 2,92 & 1,236 & 187 & 177 & $-1,042$ & ,353 & \\
\hline & R7 & 188 & 3,71 & 1,091 &,- 657 & 177 &,- 266 & ,353 & \\
\hline & R9 & 188 & 3,35 & 1,076 & -205 & 177 &,- 666 & ,353 & \\
\hline
\end{tabular}

Ayrıca araştırmada kullanılan ölçeklerin geçerlilik ve güvenilirlik analizlerinde her bir ölçeğin Cronbach Alfa değerinin 0,60 - 0,85 aralığında olduğu görülmüştür. Bu değerler ölçeklerin oldukça güvenilir olduğu anlamına gelmektedir (Kalaycı, 405: 2009). Araştırmada kullanılan ölçeklere ait değişkenlerin "Basıklık (kurtosis) ve Çarpıklık (skewness)" değerlerinin +/-2 aralığında yer aldığı ve her bir değişkene ait verilerin çoklu normal dağılıma sahip olduğu bulunmuştur.

Tablo 3. Tüketicilerin Medeni Durumlarına Göre Ev Dekorasyonunda Kullandığı Renklere İlişkin Değerlendirmeleri

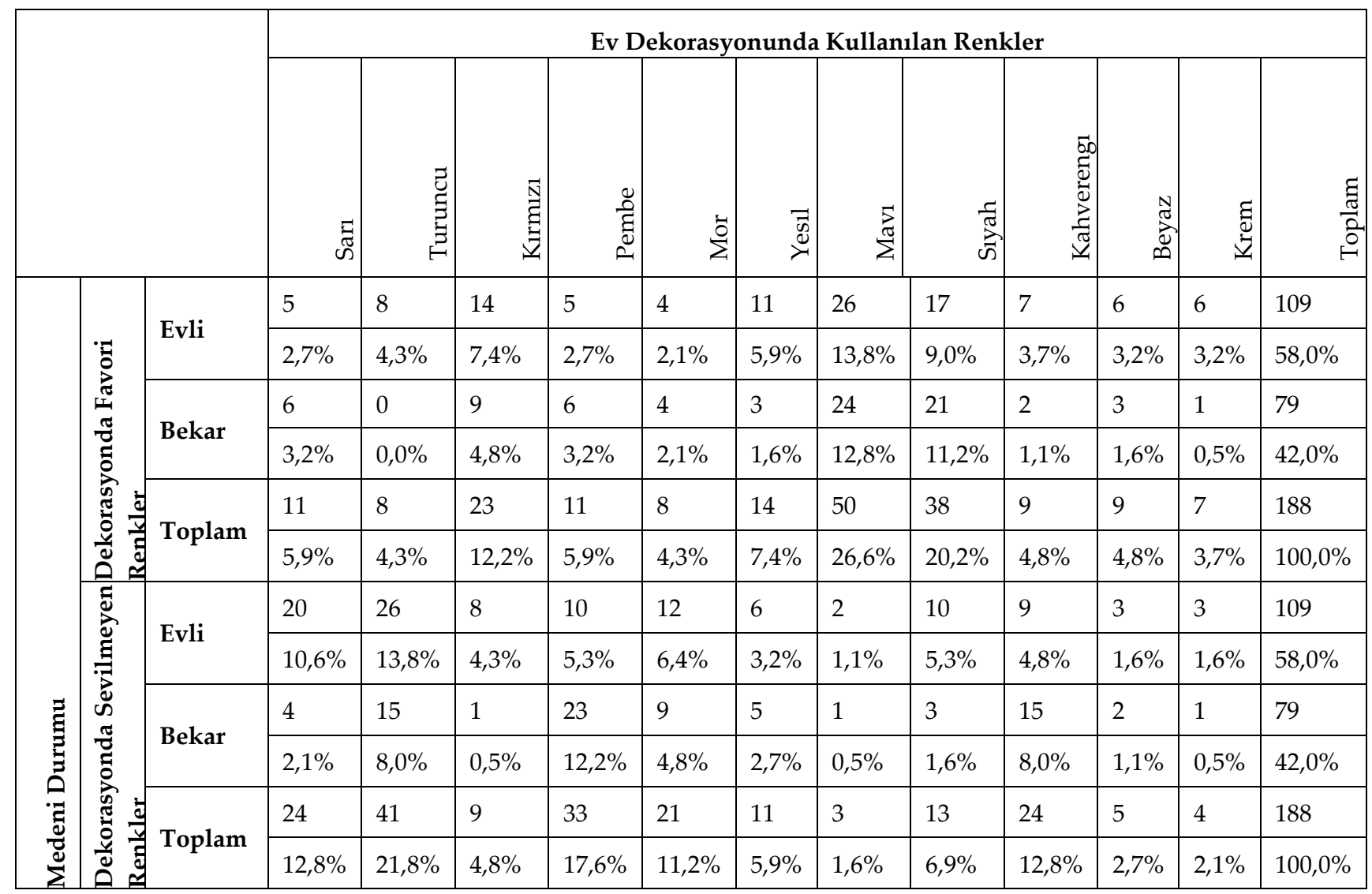

Tablo 3'te tüketicilerin medeni durumlarına göre ev dekorasyon ürünlerinde tercih ettikleri favori renkler ve ev dekorasyonunda tercih etmedikleri sevilmeyen renklere ait bulgulara yer verilmiştir. Buna göre evli 


\section{Ş. Altın - B. Çiçek 11/4 (2019) 3430-3447}

kişilerin, ev dekorasyonunda favori rengin, \%13,8 le mavi olduğu, onu sırasıyla, \%9 ile siyah, \%7,4 ile kırmızı rengin tercih edildiği görülmektedir. Evlilerde en sevilmeyen rengin ise, \%13,8'le turuncu olduğu görülmektedir. Onu sırasıyla, \%10,6 sarı, \% 6,4'le mor rengin takip ettiği görülmektedir. Bekâr kişilerin ise, ev dekorasyonunda favori rengin, \%12,8'le mavi olduğu, ikinci sirada d \%11,2 ile siyah, rengin tercih edildiği görülmektedir. Bekârlarda en sevilmeyen rengin ise, \%12,2 ile pembe olduğu, ikinci sırada ise \%8 ile turuncu rengin takip ettiği görülmektedir.

Tablo 4. Tüketicilerin Yaş Dağılımlarına Göre Ev Dekorasyonunda Kullandığı Renkler

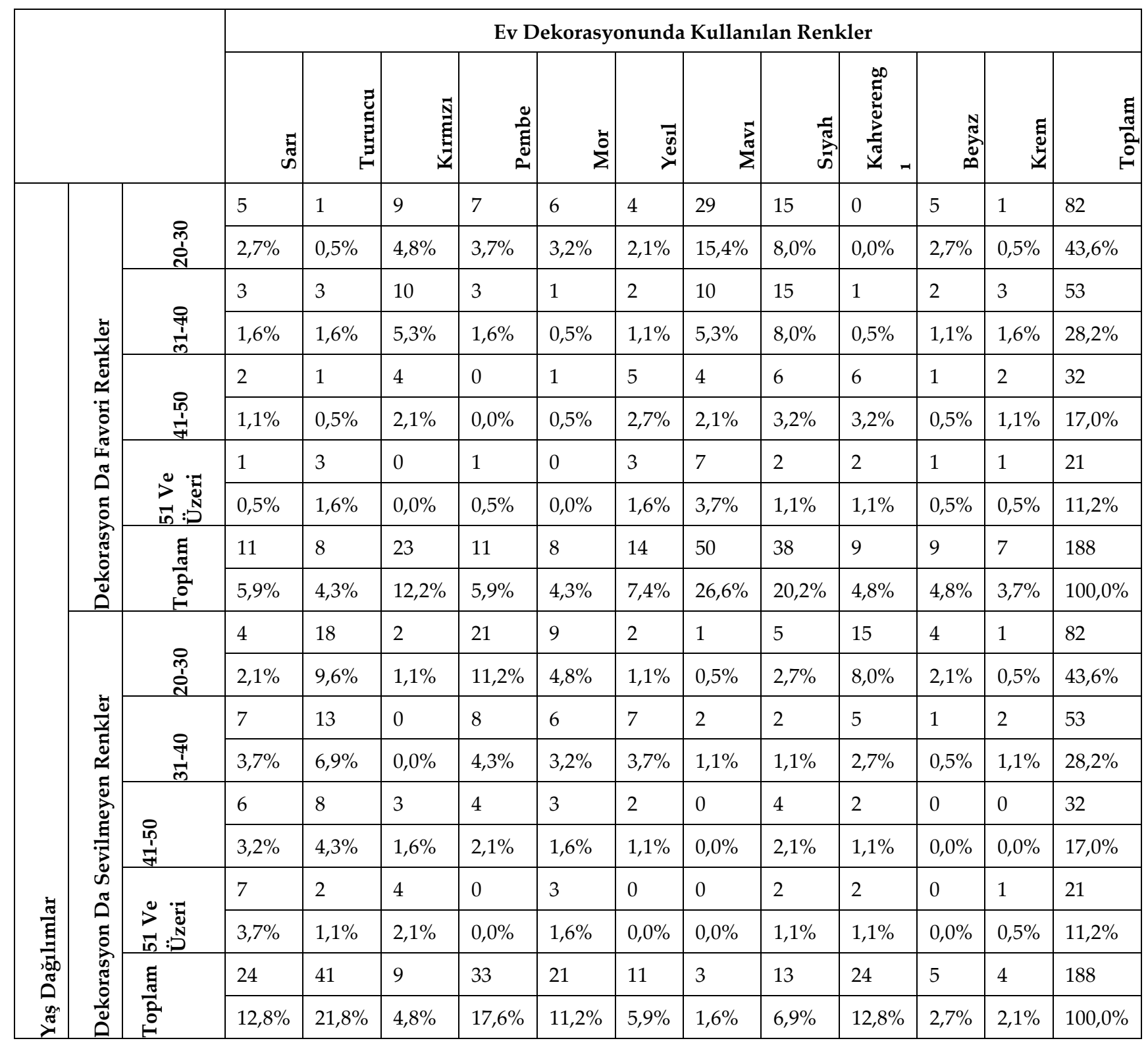

Tablo 4' de tüketicilerin yaş dağılımlarına göre ev dekorasyon ürünlerinde tercih ettikleri favori renkler ve ev dekorasyonunda tercih etmedikleri, sevilmeyen renklere ait bulgulara yer verilmiştir. Buna göre 20-30 yaş grubundaki kişilerin, ev dekorasyonunda favori rengin, \%15,4 ile mavi olduğu, onu sırasıyla, \% 8 ile siyah, $\%$ 4,8 ile kırmızı rengin tercih edildiği görülmektedir. 20-30 yaş grubundaki kişilerce en sevilmeyen rengin ise, \% 11,2 ile pembe olduğu görülmektedir. Onu sirasıyla, \% 9,6 turuncu, \% 8 ile kahverengi rengin takip ettiği görülmektedir. 31-40 yaş grubundaki kişilerin, ev dekorasyonunda favori renginin, \% 8 ile siyah olduğu, onu sırasıyla, \% 10 ile siyah, \% 10 ile mavi rengin tercih edildiği görülmektedir. 31-40 yaş grubundaki kişilerce en sevilmeyen rengin ise, \% 6,9 ile turuncu olduğu görülmektedir. Onu sırasıyla, \% 4,3 pembe rengin takip ettiği görülmektedir. 41-50 yaş grubundaki kişilerin, ev dekorasyonunda favori renginin, $\%$ 3,2 ile siyah ve kahverengi olduğu, görülmektedir. 41-50 yaş grubundaki kişilerce en sevilmeyen rengin ise, $\%$ 4,3 ile turuncu olduğu görülmektedir. 51 ve üzeri yaş grubundaki kişilerin, ev dekorasyonunda favori 
renginin, \% 3,7 ile mavi olduğu, bu grup tarafından en sevilmeyen rengin ise, \% 3,7 ile sarı olduğu görülmektedir.

Tablo 5. Tüketicilerin Cinsiyetlerine Göre Ev Dekorasyonunda Kullandığı Renkler

\begin{tabular}{|c|c|c|c|c|c|c|c|c|c|c|c|c|c|c|}
\hline & \multicolumn{12}{|c|}{ Ev Dekorasyonunda Kullanılan Renkler } \\
\hline & & & ตี & 䔍 & $\frac{\vec{N}}{\underline{\mathbf{n}}}$ & 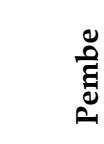 & $\dot{s}^{\tilde{a}}$ & $\begin{array}{l}\overline{\mathscr{g}} \\
\stackrel{7}{7}\end{array}$ & $\stackrel{\vec{z}}{\Sigma}$ & $\stackrel{\overbrace{}}{\tilde{n}}$ & 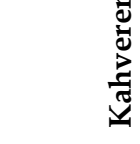 & 芯 & 跤 & 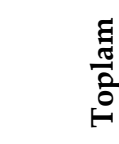 \\
\hline & \multirow{6}{*}{ 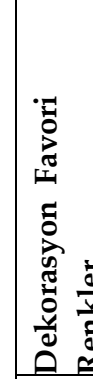 } & \multirow{2}{*}{ 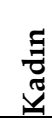 } & 6 & 4 & 15 & 11 & 8 & 11 & 21 & 20 & 3 & 6 & 6 & 111 \\
\hline & & & $3,2 \%$ & $2,1 \%$ & $8,0 \%$ & $5,9 \%$ & $4,3 \%$ & $5,9 \%$ & $11,2 \%$ & $10,6 \%$ & $1,6 \%$ & $3,2 \%$ & $3,2 \%$ & $59,0 \%$ \\
\hline & & \multirow{2}{*}{$\begin{array}{l}\text { चّ } \\
\text { 咅 }\end{array}$} & 5 & 4 & 8 & 0 & 0 & 3 & 29 & 18 & 6 & 3 & 1 & 77 \\
\hline & & & $2,7 \%$ & $2,1 \%$ & $4,3 \%$ & $0,0 \%$ & $0,0 \%$ & $1,6 \%$ & $15,4 \%$ & $9,6 \%$ & $3,2 \%$ & $1,6 \%$ & $0,5 \%$ & $41,0 \%$ \\
\hline & & \multirow{2}{*}{ 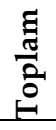 } & 11 & 8 & 23 & 11 & 8 & 14 & 50 & 38 & 9 & 9 & 7 & 188 \\
\hline & & & $5,9 \%$ & $4,3 \%$ & $12,2 \%$ & $5,9 \%$ & $4,3 \%$ & $7,4 \%$ & $26,6 \%$ & $20,2 \%$ & $4,8 \%$ & $4,8 \%$ & $3,7 \%$ & $100,0 \%$ \\
\hline \multirow{6}{*}{ 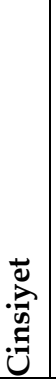 } & \multirow{6}{*}{ 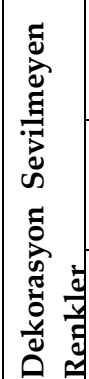 } & \multirow{2}{*}{$\begin{array}{l}\Xi \\
\tilde{\pi} \\
\underline{\pi}\end{array}$} & 15 & 31 & 1 & 9 & 13 & 5 & 2 & 10 & 22 & 3 & 0 & 111 \\
\hline & & & $8,0 \%$ & $16,5 \%$ & $0,5 \%$ & $4,8 \%$ & $6,9 \%$ & $2,7 \%$ & $1,1 \%$ & $5,3 \%$ & $11,7 \%$ & $1,6 \%$ & $0,0 \%$ & $59,0 \%$ \\
\hline & & \multirow{2}{*}{ 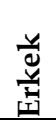 } & 9 & 10 & 8 & 24 & 8 & 6 & 1 & 3 & 2 & 2 & 4 & 77 \\
\hline & & & $4,8 \%$ & $5,3 \%$ & $4,3 \%$ & $12,8 \%$ & $4,3 \%$ & $3,2 \%$ & $0,5 \%$ & $1,6 \%$ & $1,1 \%$ & $1,1 \%$ & $2,1 \%$ & $41,0 \%$ \\
\hline & & \multirow{2}{*}{ 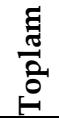 } & 24 & 41 & 9 & 33 & 21 & 11 & 3 & 13 & 24 & 5 & 4 & 188 \\
\hline & & & $12,8 \%$ & $21,8 \%$ & $4,8 \%$ & $17,6 \%$ & $11,2 \%$ & $5,9 \%$ & $1,6 \%$ & $6,9 \%$ & $12,8 \%$ & $2,7 \%$ & $2,1 \%$ & $100,0 \%$ \\
\hline
\end{tabular}

Tablo 5'de tüketicilerin cinsiyetlerine göre ev dekorasyon ürünlerinde tercih ettikleri favori renkler ve ev dekorasyonunda tercih etmedikleri sevilmeyen renklere ait bulgulara yer verilmiştir. Buna göre kadınların, ev dekorasyonunda favori renginin, \%11,2 ile mavi olduğu, onu sırasıyla, \% 10,6 ile siyah, \% 8 ile kırmızı rengin takip ettiği görülmektedir. Erkeklerde favori rengin ise, \% 15,4 ile mavi olduğu görülmektedir. İkinci sırada ise, \% 9,6 siyah rengin yer aldığı görülmektedir. Kadınların, ev dekorasyonunda sevmediği rengin ise, $\% 16,5$ ile turuncu olduğu, onu sırasıyla, \% 11,7 ile kahverengi, \% 8 ile sarı rengin takip ettiği görülmektedir. Erkeklerde sevilmeyen rengin ise, \% 12,8 ile pembe olduğu görülmektedir. İkinci sırada ise, \% 5,3 ile siyah rengin yer aldığı görülmektedir. 
Tablo 6. Tüketicilerin Mesleklerine Göre Ev Dekorasyonunda Kullandığı Renkler

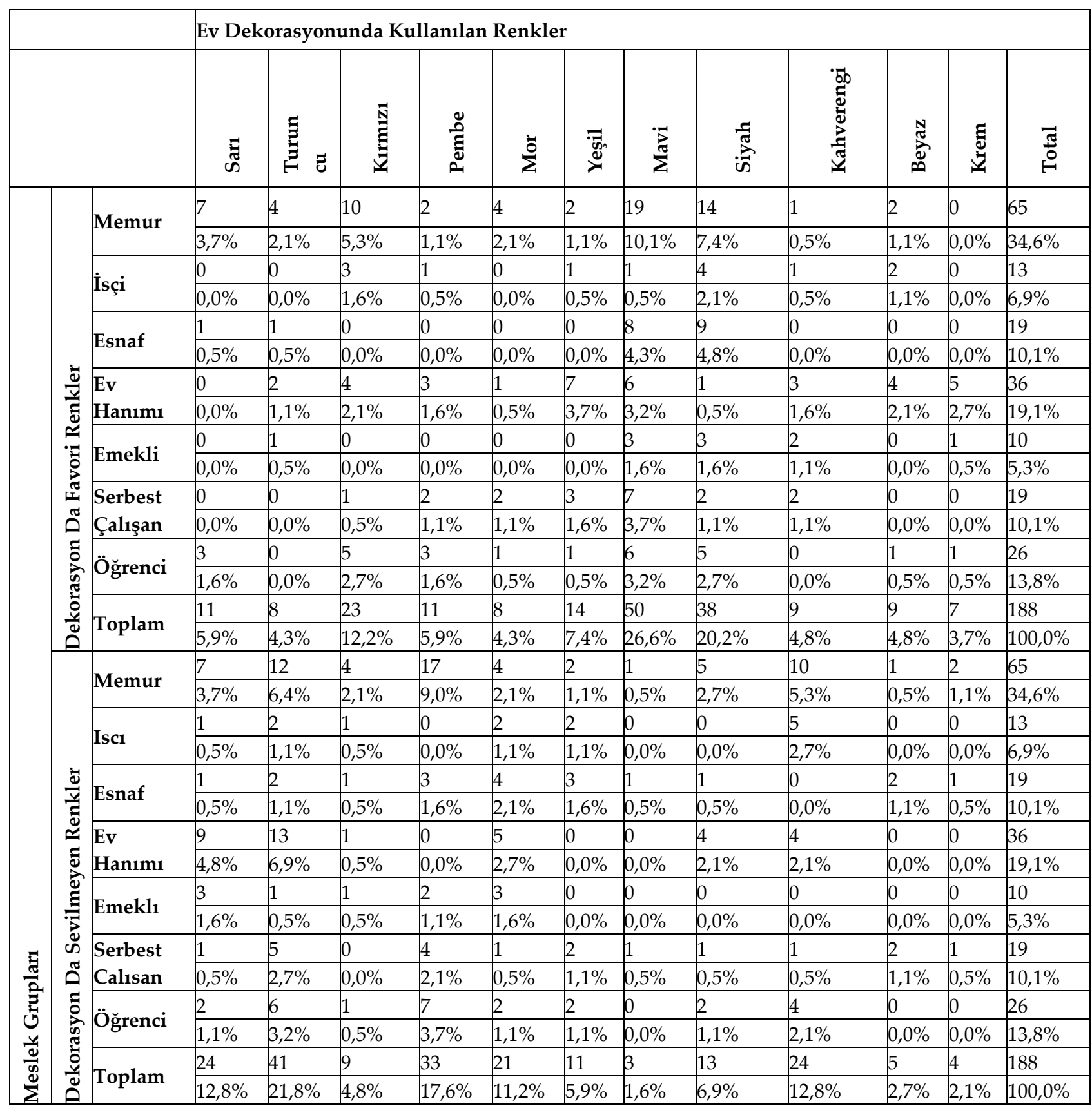

Tablo 6 'da tüketicilerin mesleklerine göre ev dekorasyon ürünlerinde tercih ettikleri favori renkler ve sevilmeyen renklere ait bulgulara yer verilmiştir. Tüketicilerin meslek gruplarına göre ev dekorasyon ürünlerinde tercih ettikleri favori renklerin, memurlarda mavi ve siyah olduğu, en sevilmeyen rengin ise pembe ve turuncu olduğu görülmektedir. işçilerde favori rengin siyah olduğu, en sevilmeyen rengin ise, mor, yeşil ve turuncu olduğu görülmektedir. Esnaflarda favori rengin, mavi ve siyah, en sevilmeyen rengin ise, mor ve yeşil olduğu görülmektedir. Ev hanımlarının favori renginin, yeşil ve mavi olduğu, en sevilmeyen rengin ise turuncu ve sarı olduğu görülmektedir. Emeklilerin favori renginin mavi olduğu, en sevilmeyen rengin ise mor ve sarı olduğu görülmektedir. Serbest çalışanların favori renginin mavi olduğu, en sevilmeyen rengin ise pembe ve turuncu olduğu görülmektedir. öğrencilerin favori renginin mavi ve kırmızı olduğu, en sevilmeyen rengin ise pembe ve turuncu olduğu görülmektedir. 
Tablo 7. Tüketicilerin Ev Dekorasyonunda Tercih Ettiği Renklerin Önemlilik Düzeyi

Tablo 7'de tüketicilerin medeni durumları, yaş dağılımları ve cinsiyetlerine göre ev dekorasyon ürünlerini

\begin{tabular}{|c|c|c|c|c|c|}
\hline & & \multicolumn{4}{|c|}{ EV DEKORASYONUNDA RENKLERİN ÖNEMLİLİK DÜZEYİ } \\
\hline & & $\begin{array}{l}\text { ÇOK } \\
\text { ÖNEMLI }\end{array}$ & $\begin{array}{l}\text { ORTA DERECEDE } \\
\text { ÖNEMLİ }\end{array}$ & $\begin{array}{l}\text { HİÇ ÖNEMİ } \\
\text { YOK }\end{array}$ & TOPLAM \\
\hline \multirow{6}{*}{ 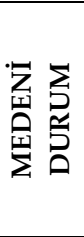 } & \multirow[t]{2}{*}{ EVLİ } & 70 & 32 & 7 & 109 \\
\hline & & $37,2 \%$ & $17,0 \%$ & $3,7 \%$ & $58,0 \%$ \\
\hline & \multirow[t]{2}{*}{ BEKAR } & 45 & 27 & 7 & 79 \\
\hline & & $23,9 \%$ & $14,4 \%$ & $3,7 \%$ & $42,0 \%$ \\
\hline & \multirow[t]{2}{*}{ TOPLAM } & 115 & 59 & 14 & 188 \\
\hline & & $61,2 \%$ & $31,4 \%$ & $7,4 \%$ & $100,0 \%$ \\
\hline \multirow{10}{*}{ 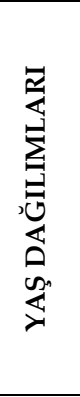 } & \multirow[t]{2}{*}{$20-30$} & 55 & 21 & 6 & 82 \\
\hline & & $29,3 \%$ & $11,2 \%$ & $3,2 \%$ & $43,6 \%$ \\
\hline & \multirow[t]{2}{*}{$31-40$} & 30 & 19 & 4 & 53 \\
\hline & & $16,0 \%$ & $10,1 \%$ & $2,1 \%$ & $28,2 \%$ \\
\hline & \multirow[t]{2}{*}{$41-50$} & 18 & 12 & 2 & 32 \\
\hline & & $9,6 \%$ & $6,4 \%$ & $1,1 \%$ & $17,0 \%$ \\
\hline & \multirow[t]{2}{*}{51 VE ÜZERİ } & 12 & 7 & 2 & 21 \\
\hline & & $6,4 \%$ & $3,7 \%$ & $1,1 \%$ & $11,2 \%$ \\
\hline & \multirow[t]{2}{*}{ TOPLAM } & 115 & 59 & 14 & 188 \\
\hline & & $61,2 \%$ & $31,4 \%$ & $7,4 \%$ & $100,0 \%$ \\
\hline \multirow{6}{*}{ 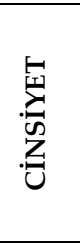 } & \multirow[t]{2}{*}{ KADIN } & 84 & 22 & 5 & 111 \\
\hline & & $44,7 \%$ & $11,7 \%$ & $2,7 \%$ & $59,0 \%$ \\
\hline & \multirow[t]{2}{*}{ ERKEK } & 31 & 37 & 9 & 77 \\
\hline & & $16,5 \%$ & $19,7 \%$ & $4,8 \%$ & $41,0 \%$ \\
\hline & \multirow[t]{2}{*}{ TOPLAM } & 115 & 59 & 14 & 188 \\
\hline & & $61,2 \%$ & $31,4 \%$ & $7,4 \%$ & $100,0 \%$ \\
\hline \multirow{16}{*}{ 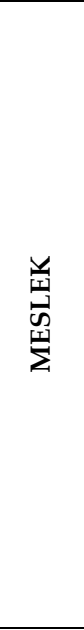 } & \multirow[t]{2}{*}{ MEMUR } & 38 & 23 & 4 & 65 \\
\hline & & $20,2 \%$ & $12,2 \%$ & $2,1 \%$ & $34,6 \%$ \\
\hline & \multirow[t]{2}{*}{ İŞÇİ } & 6 & 4 & 3 & 13 \\
\hline & & $3,2 \%$ & $2,1 \%$ & $1,6 \%$ & $6,9 \%$ \\
\hline & \multirow[t]{2}{*}{ ESNAF } & 8 & 11 & 0 & 19 \\
\hline & & $4,3 \%$ & $5,9 \%$ & $0,0 \%$ & $10,1 \%$ \\
\hline & \multirow[t]{4}{*}{ EV HANIMI } & 27 & 7 & 2 & 36 \\
\hline & & $14,4 \%$ & $3,7 \%$ & $1,1 \%$ & $19,1 \%$ \\
\hline & & 5 & 4 & 1 & 10 \\
\hline & & $2,7 \%$ & $2,1 \%$ & $0,5 \%$ & $5,3 \%$ \\
\hline & \multirow[t]{2}{*}{ SERBETS CALISAN } & 10 & 6 & 3 & 19 \\
\hline & & $5,3 \%$ & $3,2 \%$ & $1,6 \%$ & $10,1 \%$ \\
\hline & \multirow[t]{2}{*}{ OGRENCI } & 21 & 4 & 1 & 26 \\
\hline & & $11,2 \%$ & $2,1 \%$ & $0,5 \%$ & $13,8 \%$ \\
\hline & \multirow[t]{2}{*}{ Toplam } & 115 & 59 & 14 & 188 \\
\hline & & $61,2 \%$ & $31,4 \%$ & $7,4 \%$ & $100,0 \%$ \\
\hline
\end{tabular}

tercihlerinde renklerin önemlilik düzeylerine ilişkin değerlendirmelerine yer verilmiştir. Buna göre tüm grupların toplam değerlere göre ev dekorasyonunda ürünlerin rengini, $\% 61,2$ ile çok önemli bulduğu, \% 31,4'ünün, ürünlerin rengini orta derece önemsediği, \% 7,4' ünün ise renklerin tercihlerinde hiç öneminin olmadığı belirttiği görülmektedir. Medeni durumlarına bakıldığında, evlilerin, ev dekorasyonunda ürünlerin rengini, \% 37,2 ile çok önemli bulduğu, bekârlarda ise bu oranın \%23,9 olduğu görülmektedir. Evlilerin \%17'sinin, ürünlerin rengini orta derece önemsediği, bekârlarda ise bu oranın \%14,4 olduğu görülmektedir. Evlilerin ve bekârların \% 3,7 ile ürünlerin renginin dekorasyonda önemine ilişkin “hiç önemli değil" şeklinde görüş bildirdiği görülmektedir. Yaş gruplarına göre renklerin önemine ilişkin değerlendirmelere bakıldığında, 20-30 yaş grubunun, ev dekorasyonunda ürünlerin rengini, \% 29,3'nun çok önemli bulduğu, 31-40 yaş grubunda bu oranın \%16, 41-50 yaş grubunda $\% 9,6,51$ ve üzeri yaş grubunda ise $\% 6,4$ olduğu görülmektedir. Cinsiyet gruplarına göre renklerin önemine ilişkin değerlendirmelere bakıldığında, kadınların \%44,7 ile ile çok önemli bulduğu, erkelerde ise bu oranın \% 16,5 olduğu görülmektedir. Erkeklerin \%19,7'sinin ürünlerin rengini orta derece önemsediği, kadınlarda ise bu oranın $\% 11,7$ olduğu görülmektedir. Kadınların sadece \%2,7 sinin renklerin hiç önemi yok görüşüne sahip olduğu görülürken, erklerde bu oranın, $\% 4,8$ olduğu görülmüsstür. Meslek gruplarına göre renklerin önemine ilişkin değerlendirmelere bakıldığında, memurların, ev dekorasyonunda ürünlerin rengini, \% 20,2' sinin çok 
önemli bulduğu, işçilerde bu oranın \%3,2, 41-50 esnaflarda \%4,3, ev hanımlarında \%14,4, emeklilerde \% 2,7, serbest çalışanlarda $\% 5,3$ ve öğrencilerde ise $\% 11,2$ olduğu görülmektedir. Meslek gruplarına göre renklerin önemine ilişkin değerlendirmelere bakıldığında, memurların, ev dekorasyonunda ürünlerin rengini, \% 20,2' sinin çok önemli bulduğu, işçilerde bu oranın \%3,2, $41-50$ esnaflarda \%4,3, ev hanımlarında \%14,4, emeklilerde \% 2,7, serbest çalışanlarda $\% 5,3$ ve öğrencilerde ise $\% 11,2$ olduğu görülmektedir

Tablo 8. Araştırma Hipotezlerinin Analiz Sonuçları

\begin{tabular}{|l|l|l|l|}
\hline Hipotezler & $\begin{array}{l}\text { İstatistik } \\
\text { değeri }\end{array}$ & P değeri & Kabul/Red \\
\hline $\begin{array}{l}\text { H1: Tüketicilerin satın alma kararları cinsiyetlerine göre farklılık } \\
\text { gösterir }\end{array}$ & $\mathrm{t}=4,382$ & $\mathrm{P}=, 000$ & Kabul \\
\hline $\begin{array}{l}\text { H2: Tüketicilerin satın alma kararları gelir düzeylerine göre } \\
\text { farklılık gösterir. }\end{array}$ & $\mathrm{F}=1,791$ & $\mathrm{P}=, 132$ & $\mathrm{Red}$ \\
\hline $\begin{array}{l}\text { H3: Tüketicilerin satın alma kararları öğrenim durumlarına göre } \\
\text { farklılık gösterir }\end{array}$ & $\mathrm{F}=, 259$ & $\mathrm{P}=, 772$ & $\mathrm{Red}$ \\
\hline $\begin{array}{l}\text { H4: Tüketicilerin satın alma kararları meslek gruplarına göre } \\
\text { farklılı gösterir }\end{array}$ & $\mathrm{F}=3,520$ & $\mathrm{P}=, 003$ & Kabul \\
\hline $\begin{array}{l}\text { H5: Tüketicilerin renklere ilişkin değerlendirmeleri } \\
\text { cinsiyetlerine göre farklılık gösterir }\end{array}$ & $\mathrm{t}=3,740$ & $\mathrm{P}=, 000$ & Kabul \\
\hline $\begin{array}{l}\text { H6: Tüketicilerin renklere ilişkin değerlendirmeleri gelir } \\
\text { düzeylerine göre farklılık gösterir. }\end{array}$ & $\mathrm{F}=, 934$ & $\mathrm{P}=, 445$ & Red \\
\hline $\begin{array}{l}\text { H7: Tüketicilerin renklere ilişkin değerlendirmeleri öğrenim } \\
\text { durumlarına göre farklılık gösterir }\end{array}$ & $\mathrm{F}=1,132$ & $\mathrm{P}=, 267$ & Red \\
\hline $\begin{array}{l}\text { H8: Tüketicilerin renklere ilişkin değerlendirmeleri meslek } \\
\text { gruplarına göre farklılık gösterir }\end{array}$ & $\mathrm{F}=3,532$ & $\mathrm{P}=, 002$ & Kabul \\
\hline $\begin{array}{l}\text { H9: Tüketicilerin renklere ilişkin değerlendirmeleri ile satın } \\
\text { alma kararları arasında ilişki vardır. }\end{array}$ & $\mathrm{r}=, 673$ & $\mathrm{P}=, 000$ & Kabul \\
\hline $\begin{array}{l}\text { H10: Tüketicilerin renklere ilişkin değerlendirmeleri, satın alma } \\
\text { kararlarını etkiler. }\end{array}$ & $\mathrm{B}=, 810$ & $\mathrm{P}=, 000$ & Kabul \\
\hline *p <0,05 (istatistiksel anlamlılık düzeyi), t: t-testi, F: Anova, r: korelasyon, B: regresyon & \\
\hline
\end{tabular}

Tablo $8^{\prime}$ de araştırma modeline ait hipotezlerin test sonuçları yer almaktadır. Bağımsız ikili grupların testinde bağımsız t-testi, çoklu grupların testinde ANOVA analizi kullanılmıştır. ANOVA analizi yapılmadan önce varyansların dağılımın homojen olduğu, verilerin normal dağılıma sahip olduğu görülmüştür. Varyans analizinde Tukey, Duncan ve Scheffe yöntemleri kullanılmıştır. Bağımsız değişkenlerin bağımlı değişken üzerindeki etkileri doğrusal regresyon analizi ile, değişkenler arasındaki ilişkiler ise korelasyon analizi test edilmiştir. Korelasyon analizi Pearson Korelasyon yöntemine göre yapılmıştır. H1 hipotezinde, tüketicilerin satın alma kararlarının cinsiyetlerine göre farklılık gösterdiği ön görülmüştür. Hipotezin testinde bağımsız $t$-testi kullanılmıştır. $T$ değerinin $t=4,38, P$ değerinin $p=, 000$ olduğu görülmüştür. Bu durumda $\mathrm{H} 1$ hipotezi kabul edilmiştir. Buna göre tüketicilerin ev dekorasyon ürünlerini satın almalarında erkek ve kadınlar arasında görüş farklılıkları olduğu görülmektedir. H2 hipotezinde, tüketicilerin satın alma kararlarının gelir düzeylerine göre farklılık gösterdiği varsayılmaktadır. Hipotezin testinde bağımsız one way anova test istatistiği kullanılmıştır. F değeri 1,791, $\mathrm{P}=, 132$ olduğundan hipotez red edilmiştir. Buna göre tüketicilerin ev dekorasyon ürünlerini satın almalarında gelir düzeylerine göre görüş farklılıkları bulunmamaktadır. H3 hipotezinde Tüketicilerin satın alma kararlarının öğrenim durumlarına göre farklılık gösterdiği varsayılmaktadır. $F$ değeri ,259, P=,772 olduğundan hipotez red edilmiştir. Buna göre tüketicilerin ev dekorasyon ürünlerini satın almalarında öğrenim durumlarına göre görüş farklılıkları bulunmamaktadır. H4 hipotezinde, Tüketicilerin satın alma kararlarının meslek gruplarına göre farklılık gösterdiği varsayılmaktadır. $F$ değeri 3,520 ve $P=, 003$ olduğundan hipotez kabul edilmiştir. Buna göre tüketicilerin ev dekorasyon ürünlerini satın almalarında meslek gruplarına göre görüş farklılıkları bulunmamaktadır. Memurların, ev dekorasyon ürünlerini satın alma konusunda işçilere, ev hanımlarına ve öğrencilere göre farklı görüşlere sahip olduğu görülmektedir. 
İşçilerinde esnaflara göre farklı görüşlere sahip olduğu yine aynı analizi sonuçlarındandır. Ev hanımlarının ise, işçiler ve serbest çalışanlarla farklı görüşlere sahip olduğu görülmektedir. H5 hipotezinde tüketicilerin renklere ilişkin değerlendirmelerinin cinsiyetlerine göre farklılık gösterdiği varsayılmaktadır. T değeri 3,740 ve $\mathrm{P}=, 000$ olduğundan hipotez kabul edilmiştir. Buna göre tüketicilerin ev dekorasyon ürünlerinin renklerine ilişkin görüşlerinin erkek ve kadınlar arasında farklı olduğu görülmektedir. H6 hipotezinde tüketicilerin renklere ilişkin değerlendirmelerinin gelir düzeylerine göre farklılık gösterdiği varsayılmaktadır. F değeri ,934 ve P değeri ,445 olduğundan hipotez red edilmiştir. H7 hipotezinde, tüketicilerin renklere ilişkin değerlendirmelerinin öğrenim durumlarına göre farklılık gösterdiği varsayılmaktadır. Fdeğeri 1,132 ve $\mathrm{P}$ değeri ,267 olduğundan hipotez red edilmiştir. H8 hipotezinde tüketicilerin renklere ilişkin değerlendirmelerinin meslek gruplarına göre farklılık gösterdiği varsayılmaktadır. F değeri 3,532 ve $\mathrm{P}=, 002$ olduğundan hipotez kabul edilmiştir. Buna göre tüketicilerin ev dekorasyon ürünlerinin renklerine ilişkin değerlendirmelerinin meslek gruplarına göre farlılık göstermektedir. Memurların, ev dekorasyon ürünlerinin renkleri konusunda işçilere ve ev hanımlarına göre farklı görüşlere sahip olduğu görülmektedir. İşçilerinde memur, ev hanımı ve öğrencilere göre farklı görüşlere sahip olduğu, ev hanımlarının ise, memur, işçi, esnaf, emekli ve serbest çalışanlarla farklı görüşlere sahip olduğu görülmektedir. H9 hipotezinde tüketicilerin renklere ilişkin değerlendirmeleri ile satın alma kararları arasında ilişki olduğu varsayılmaktadır. Korelasyon ( $r$ değeri), 673 ve $p$ değeri ,000 olduğundan hipotez kabul edilmiştir. Bu durumda tüketicilerin renklere ilişkin değerlendirmeleri ile satın alma davranışları arasında pozitif yönlü bir ilişki vardır. H10 hipotezinde, tüketicilerin renklere ilişkin değerlendirmelerinin, satın alma kararlarını etkilediği varsayılmaktadır. $\quad$ Bu etki $(\beta=, 810$ ve $p<0,000)$ olduğundan istatistiksel olarak anlamlıdır. Buna göre, tüketicilerin ev dekorasyon ürünlerinin renklerine ilişkin değerlendirmeleri, satın alma davranışlarını pozitif yönlü ve doğrudan etkilediği görülmektedir. Bu durumda H10 hipotezi kabul edilmiştir.

\section{Sonuç ve Öneriler}

Tüketicilerin ev dekorasyon ürünlerini satın almalarında renklerin etkilerine ilişkin değerlendirmelerinin yer aldığı bu araştırmada, satın alma davranışları ile ürünlerin renklerine ilişkin değerlendirmelerin demografik değişkenlere (cinsiyet, gelir durumu, meslek, medeni durum, öğrenim durumu v.b.) göre farklılık gösterip göstermediği incelenmiştir. Araştırmadan elde edilen bulgulara göre, satın alma davranışlarının kadınlar ve erkekler arasında farlılık gösterdiği gözlenmiştir. Bu farklılığın renk tercihinde de ortaya çıtığı görülmektedir. Kadınlar ve erkeklerde, dekorasyon ürünlerini tercih ederken favori renginin güven, güç, sakinlik ve otorite gibi anlamları kapsayan mavi renk olduğu görülmektedir. Yılmaz ve Erden (2017) tarafından yapılan diğer bir araştırmada, beyaz, sarı ve mavi renklerin, kişilerin tüketim alışkanlıklarına etkisi incelenmiş ve mavi renklerin erkekler üzerinde daha az tüketim etkisi yarattığı sonucuna ulaşılmıştır (Cho vd., 2015). Bu araştırmada ayrıca renklerin psikolojik etkisinin cinsiyete göre değişebileceğinden söz edilmektedir. Renklerle ilgili genel kabullerin aksine; psikolojik etkiler, tercihler, kültür, yaş gibi demografik özelliklerinde renk seçiminde etkisi olduğunu söylenmektedir. Ustaoğlu (2007) tarafından yapılan çalışma sonucunda, cinsiyetler arasında renk tercihi ve renk kullanımı arasında anlamlı bir ilişki olduğu saptanmıştır. Bu açıdan araştırma sonuçları ile tutarlılık göstermektedir. Memiş (2007) tarafından yapılan çalışma sonucunda, kadın ve erkekler arasında renk algısının farklı olmadığı sonucuna ulaşılmıştır. Bu sonuca göre kadınlar ve erkekler arasındaki renk tercihinin kişilerin beğenilerine göre değişik gösterdiği tahmin edilmektedir. Araştırma sonuçları gösteriyor ki kadınların ve erkeklerin renk tercihleri farlılık göstermektedir. Tüketicilerin yine meslek gruplarına göre ev dekore ederken kullandıkları dekorasyon ürünlerinde tercih ettikleri renkler farklılık göstermiştir. Araştırmadan elde edilen bir diğer bulgulara göre tüketicilerin ev dekorasyon ürünlerini satın almalarında meslek gruplarına göre görüş farklılıkları bulunmaktadır. Memurların, ev dekorasyon ürünlerini satın alma konusunda işçilere, ev hanımlarına ve öğrencilere göre farklı görüşlere sahip olduğu görülmektedir. İşçilerinde esnaflara göre farklı görüşlere sahip olduğu görülmektedir. Ev hanımlarının ise, işçiler ve serbest çalışanlarla farklı görüşlere sahip olduğu görülmektedir. Meslek grupları içinde ev hanımlarının belirgin bir şeklide diğer meslek gruplarına göre ev dekorasyon tercihlerinde farklı görüşlere sahip olduğu gözlenmektedir. Bu farklılıkların ev dekorasyon ürünlerin birincil kullanıcılarının kadınlar olmasından kaynakladığı düşünülmektedir. Dolayısıyla ev dekorasyonu ürünlerini tercih edecek kişi kadın ve ev hanımı ise işletmeler şunu unutmamalıdır ki rengin çok fazla önemi vardır. Eti İçli ve Çopur (2008) tarafından yapılan çalışmada, pazarlama iletişiminde görsel unsurlardan özellikle rengin etkisinin olduğu düşülmüştür. Çalışma sonucunda, renklerin öncelikle görsel 
olarak dikkat çekiciliği sağlayarak tüketicinin ürüne yönelmesini sağlarken, alışveriş yapılan ortamların renkleri de tüketici davranışlarına yansıttığını, özellikle kurum kimliği, bu yansıma daha net bir biçimde görüldüğü sonucuna ulaşılmıştır. Tüketicilerin yaş dağılımı, cinsiyet ve medeni durumlarına göre ev dekorasyon ürünlerinde renklerin ne derece önemli olduğuna ilişkin değerlendirmelerine bakıldığında tüm grupların ev dekorasyonunda ürünlerin rengini, \% 61,2 ile çok önemli bulduğu, \% 31,4'ünün, ürünlerin rengini orta derece önemsediği, \% 7,4' ünün ise renklerin tercihlerinde hiç öneminin olmadığı belirttiği görülmektedir. Medeni durumlarına bakıldığında, evlilerin, ev dekorasyonunda ürünlerin rengini, çok önemli bulduğu, bekârların ise orta derece önemsediği görülmektedir. Yaş gruplarına göre renklerin önemine ilişkin değerlendirmelere bakıldığında, 20-30 yaş grubunun, ev dekorasyonunda ürünlerin rengini çok önemli bulduğu görülmektedir. Dittmar (2001)'ın renk tercihlerini renk isimleri yöntemiyle yaptığ1 araştırmasında, Almanlar'ın en çok tercih ettiği rengin mavi renk olduğu bildirilmektedir. Bu araştırmada renk tercihlerinin yaşam boyunca değiştiği ortaya konulmuş, genç, yetişkin ve yaşlı arasındaki farklılıkları ölçmek için daha çok çalışma yapılmasını önerilmiştir (Yılmaz ve Erden, 2017: 268). Dolayısıyla alışveriş esnasında dekorasyon ürünlerinin (halı, perde, saat aksesuar ) tercihi yapılırken satış elemanlarının 20-30 yaş aralığındaki kişilere ürünleri pazarlarken renge verdikleri önemi bilerek o şekilde yaklaşmaları gerekilebilir. Yine cinsiyet gruplarına göre renklerin önemine ilişkin değerlendirmelere bakıldığında kadınların çok önemli bulduğu, erkeklerin ürünlerin rengini orta derece önemsediği görülmektedir. Bu sonuçlara göre dikkat edilmesi gereken unsur ev dekorasyonu tamamlayıcı parçalarının tercihinde söz konusu alışverişi yapan kişi eğer kadın ise odanın dizaynında kullanılan renklerin yoğunluğu sorularak ona göre tavsiyelerde bulunulabilir. Bir diğer renklerin önemine ilişkin değerlendirme de meslek gruplarıdır. Meslek gruplarına bakıldığında, memurların, ev hanımlarının ve öğrencilerin ev dekorasyonunda ürünlerin rengini, çok önemli bulduğu, işçilerde, esnaflarda, emeklilerde ve serbest çalışanlarda orta derece önemsediği olduğu görülmektedir. Tüketicilerin renklere ilişkin değerlendirmeleri ile satın alma kararları arasında pozitif yönlü ilişki ve etki olduğu görülmektedir. Bu durumda tüketicilerin renklere ilişkin değerlendirmelerine etki eden faktörlerin artırılması durumunda satın alma davranışlarının pozitif yönlü etkileneceği ve satın almaların artı̧̧ göstereceği beklenmektedir. Şen (2015) tarafından Bursa ilinde yapılan çalışmada; bir iletişim aracı olan renklerin her birinin farklı anlamlar ifade ettiği, bir algı ve duygu yarattığı gerçeği düşünülerek, pazarlama uygulamalarının her alanında bu unsurun üstlendiği rolün yorumlanması amaçlanmıştır. Çalışma sonucunda, bir simgesel iletişim aracı olan renk, pazarlama iletişimindeki uygulamalarında, güçlü anlamları ve ifade ettikleri ile tüketicilerin algısında ve satın alma davranışlarında direkt etkili bir konumda olduğu bilgisi ortaya çıkmıştır. Bu sonuç araştırma sonuçlarıyla tutarlılık göstermektedir. Araştırma sonuçları genel olarak değerlendirildiğinde, kuşkusuz ev dekore ederken kullanılan renklerin büyük önem taşıdığı ve tercihleri etkilediği söylenilebilir. Ayrıca cinsiyet, medeni durum, yaş ve mesleğe göre kişiler dekorasyon ürün tercihinde bulunurken renklerin taşıdıkları anlamlara ve kişilerde uyandırdığı etkilere bakarak tercih ettikleri söylenilebilir. Dolayısıyla ev dekorasyon ürünlerini üreten işletmelerin ve işletmelerdeki satış elemanlarının, faaliyete geçmeden önceki analiz kısmında, elde edilen bu sonuçlardan faydalanmaları önerilebilir. Ancak araştırmanın ana kütlesinin Yozgat ili ile sınırlı olması elde edilen sonuçların genel geçerliliğini etkilemektedir. Bu nedenle benzer çalışmaların farklı illerde ve bölgelerde yapılması önerilmektedir. Bunun dışında benzer bir araştırmanın bilgi paylaşımına açık, farklı örneklem grupları üzerinde yürütülmesi durumunda daha farklı sonuçlar elde edilebileceği ön görülmektedir. Renk ve satın alma kararları pazarlamada yer edinmiş çalışma alanına sahip olduğundan elde edilen bulguların ve oluşturulan modelin ileride yapılacak araştırmalara kaynak oluşturabileceği düşünülmektir. 


\section{Ş. Altın - B. Çiçek 11/4 (2019) 3430-3447}

\section{Kaynakça}

Ahbap Öztürk, B., (2014), Renklerin Pazarlama Üzerindeki Etkisi, İstanbul Kültür Üniversitesi Sosyal Bilimler Enstitüsü, Yüksek Lisans tezi, İstanbul.

Akbaş, E., (2006), Otomobil İç Tasarımında Renk - Kullanıcı - Pazarlama İlişkisi, Marmara Üniversitesi Güzel Sanatlar Enstitüsü, Yüksek Lisans Tezi, İstanbul.

Akgül, D., ve Güneş, D. (2015). Renkler, Anlamları ve Marka Bilinirliği Üzerindeki Etkisi: Kırşehir Örneği. 14. Ulusal İşletmecilik Kongresi. Aksaray.

Akkuş Karkın, G. (2009), Otel İşletmelerinde Hizmet atmosferinin Oluşturulması: Kavramsal Bir Çalışma, Sosyal Bilimler dergisi, 11/2, s.165-181.

Bahattin, H., (2013), Tüketicinin Satın Alma Kararı Üzerinde Ambalaj Renklerinin Önemi Ve Grafik Tasarım Öğrencilerinin Konu Üzerindeki Farkındalığının Ölçülmesi, Gazi Üniversitesi Eğitim Bilimleri Enstitüsü, Yüksek Lisans tezi, Ankara.

Baykaldı, R., (2015), Tüketicilerin Mağaza Atmosferi Faktörlerinden Renk, Müzik Ve Koku'ya Karşı Tutumları, Marmara Üniversitesi Sosyal Bilimleri Enstitüsü, Yüksek Lisans Tezi, İstanbul.

Ceylan, İ. G., ve Eliri, İ., (2014), Ambalaj Tasarımında Kullanılan Subliminal Mesaj Öğeleri Ve Satın Alma İlişkisi, Akademik Sosyal Araştırmalar Dergisi, 2/8, s. 410-419, Aralık.

Cho., S., Han, A., Taylor, M., Huck, A., Mishler, A., Mattal, K., Berker, C. ve Seo, H. (2015). Blue Lighting Decreases The Amount of Food Consumes in Men But Not in Women, Appetite, 85, 111,117.

Çeken, B., ve Yıldız, E., (2015), Renklerin Reklam Algısı Üzerindeki Etkisï: 2012 Kırmızı Reklam Ödülleri, Sanat Eğitimi Dergisi, 3/2, s.129-146.

Çitoğlu, S., (2008), 1945 Yılı Sonrası Afişlerdeki Renklerin Psikolojik Boyutları, Gazi Üniversitesi Eğitim Bilimleri Enstitüsü, Yüksek Lisans Tezi, Ankara.

Durmaz, Ö., (2009), Hızlı Tüketim Ürünlerinin Ambalaj Tasarımlarında Çağrışımsal Öğrenme İle Renk Kararları, Dokuz Eylül Üniversitesi Güzel Sanatlar Enstitüsü, Yüksek Lisans Tezi, İzmir.

Ellialtı, Y., (2009), Ürün Özellikleri, Görece Ürün Kalitesi Ve Tüketici Etnosentrizminin Yerli Ürün Satın Alma Eğilimine Etkisi: Kozmetik Sektöründe Bir Uygulama, Marmara Üniversitesi Sosyal Bilimler Enstitüsü, Yüksek Lisans Tezi, İstanbul.

Elliot, A.J., and Maier M.A. "Color and Psychological Functioning”, Current Directions in Psychological Science, vol. 16 no. 5, October 2007, s. 250-254.

Engel, F.J., Blackwell, R.D., and Miniard, P.W. Consumer Behavior, The Dryden Press, Forth Worth, 1995.

Eti İçli, G., ve Çopur, M., (2008), Pazarlama İletişiminde Renklerin Rolü, Trakya Üniversitesi Sosyal Bilimler Dergisi, 10/1, s.22-33, Haziran.

Dittmar. M. (2001). Changing Colour Preferences with Ageing: A Comparative Study on Younger and Older Native Germens Aged 1990 Years. Gerontology 2001;47:219 226.

Grossman R. P., and Wisenblit, J.Z. "What we know about consumers' color choice", Journal of Marketing Practice, Vol. 5 no: 3, 1999, s.78-88.

Gönen, E., ve Özmete, E., (2007), Tüketicilerin Gıda ve İçecek Ambalajlarında Materyal, Büyüklük ve Renk Tercihleri, Pazarlama Dünyası, 21/3, ss. 53-57.

İpek, B., (2014), Çocuklardaki Yalnızlık Duygusunun Resimlerinde Kullandıkları Renklere Yansıması, Gazi Üniversitesi Eğitim Bilimleri Enstitüsü , Yüksek Lisans Tezi.

Kalaycı, Ş., (2009), "SPSS Uygulamalı Çok Değişkenli İstatistik Teknikleri”, Asil Yayın Dağıtım Ltd., 4. Baskı, Ankara.

Koca, E.,ve Koç, F., (2008), Çalışan Kadınların Giysi Seçimleri Ve Renk Tercihleri, Elektronik Sosyal Bilimler Dergisi, 7/24, s.171-200. 


\section{Ş. Altın - B. Çiçek 11/4 (2019) 3430-3447}

Madden,T.J., Hewett, K., and Roth, M. S. “Managing Images in Different Cultures: A Cross National Study of Color Meanings and Preferences" Journal of International Marketing, Vol: 8/4, 2000, s.90-107.

Mehmeti, N., (2003), Kurum Kültürünün Kurum Kimliğine, Ürün Kimliğine ve Ambalaj Tasarımına Yansıması, Marmara Üniversitesi Güzel Sanatlar Enstitüsü , Yüksek Lisans Tezi, İstanbul.

Memiş; Ö., (2007), Renk Algısının Algısal Organizasyonunun Bireysel Farklılıklar Metodu İle Değerlendirilmesi Ve Renk Algısında Cinsiyet Farklılıkları, İstanbul Üniversitesi Sosyal Bilimler Enstitüsü, Yüksek Lisans Tezi, İstanbul.

Odabaşı, Y., ve Barış, G., (2013), Tüketici Davranışı, MediaCat, Eskişehir.

Özcan, M., (2018), Renklerin Tüketimde Ve Sağlıta Önemi, Derleme (Review), 1/3, S.83-88, Temmuz.

Özdemir, T., (2005), Tasarımda Renk Seçimini Etkileyen Kriterler, Çukurova Üniversitesi. Sosyal Bilimler Enstitüsü Dergisi, 14/2, s.391-402.

Özer, D., (2012), Toplumsal Düzenin Oluşmasında Renk Ve İletişim, ODÜ Sosyal Bilimler Enstitüsü Sosyal Bilimler Araştırmaları Dergisi, 3/6, s.265-281, Aralık.

Öztuna, H.Y., (2007), Temel Tasarım Öğeleri: Renk, Grafik Tasarım - Görsel İletişim Kültürü Dergisi, 8 s.8891.

Sarıkaya, N., ve Sütütemiz, N., (2004), Tüketicilerin Satın Alma Davranışı ve Yaşam Tarzı Üzerinde Renklerin Etkisine Yönelik Bir Araştırma, 3. Ulusal Bilgi, Ekonomi ve Yönetim Kongresi., Eskişehir Osmangazi Üniversitesi, s.221-229.

Spence, C. (2015). On The Psychological İmpact of Food Color. Spence Flavour, 4:21, DOI 10.1186/s13411 01500313

Şen, A., (2015), Pazarlamada Renk Unsuru ve Bir Araştırma, Okan Üniversitesi Sosyal bilimler Enstitüsü, Yüksek Lisans Tezi, Bursa.

Tabachnick, Barbara G. and Fidell, Linda S., (2012), "Using Multivariate Statistics”, sixth editıon, Copyright By Pearson Education, Inc. All Rights Reserved. Manufactured İn The United States Of America.

Ustaoğlu, E., (2007), Renklerin İnsan Yaşamındaki Yeri, Maltepe Üniversitesi Sosyal Bilimler Enstitüsü, Yüksek Lisans Tezi, İstanbul.

Yazıcı, G., (2009), Tüketicilerin Yaşam Tarzlarına Bağlı Olarak Ürün Ambalajı Rengi Tercihleri: Bir Araştırma, Marmara Üniversitesi Sosyal Bilimler Enstitüsü, Yüksek Lisans Tezi, İstanbul.

Yılmaz, H., Erden, G., (2017), Renklerin Çorbaların Tat Algısı Üzerindeki Etkilerini Belirlemeye Yönelik Bir Araştırma, Journal of Tourism and Gastronomy Studies, 5/2, s.265-275. 